\title{
A life less ordinary: analysis of the uniquely preserved tattooed dermal remains of an individual from 19th century France
}

\author{
Martin J. Smith ${ }^{1} \cdot$ A. Starkie ${ }^{2} \cdot$ R. Slater ${ }^{1} \cdot$ H. Manley ${ }^{3}$ \\ Received: 17 June 2019 / Accepted: 21 January 2021 / Published online: 26 February 2021 \\ (C) The Author(s) 2021, corrected publication 2021
}

\begin{abstract}
'Anthropologies of the Body' often view the human form as a sort of text, onto which meanings and experiences are inscribed during people's lives, rendering the body effectively as an artefact of material culture. Such 'inscription' is generally metaphorical; however, in the case of tattooing, aspects of the way people wish to be perceived are quite literally inscribed upon the body. The current article presents analysis of an unusual 'artefact' in the form of the major anterior portion of the preserved, tattooed skin of an adult male. The skin's provenance was previously unknown, as was the reason why he had been subject to such treatment after death. The current project has progressed towards resolving these issues using multiple approaches, including CT scanning, multispectral light sources, infrared reflectography and spectroscopic dating. The latter technique produced a date range of $1861 \pm 15$ years for the wood on which the skin was mounted. Multispectral and infrared light examination made it possible to discern many of the tattooed motifs much more clearly. The images and text that were made visible suggested this man had been French and had probably spent time overseas, possibly in naval service. Towards the end of his life, he may have been imprisoned and the date ' 1883 ' was decipherable. The current analysis allowed the investigators to glean far more information than was initially expected, providing a considerably richer personal narrative of this individual through the content of his tattoos than is usually possible in biological anthropology.
\end{abstract}

Keywords Tattooing $\cdot$ Soft-tissue preservation $\cdot$ Mummification $\cdot$ Computerised tomography $\cdot$ Infrared $\cdot$ Osteobiography

\section{Introduction}

The notion that the preserved remains of past people can constitute a sort of text in which the events, actions and experiences undergone by an individual during their lifetime have left encoded signs, waiting to be read, is one of the most common metaphors in biological anthropology. The vast majority of studies in the field involve the analysis of excavated bones and teeth, as these hard tissues are commonly the only portions of the body to survive in burial environments that are otherwise conducive to decay. Soft tissues, including skin,

Martin J. Smith

mjsmith@bournemouth.ac.uk

1 Department of Archaeology and Anthropology, Bournemouth University, Poole, UK

2 International Committee of the Red Cross, 19 Avenue de la Paix, 1202 Geneva, Switzerland

3 Department of Life and Environmental Sciences, Bournemouth University, Poole, UK generally survive only in specific and fairly unusual conditions and are therefore relatively uncommon in most regions. Cultural modifications of the outward parts of the body such as tattoos, therefore, appear even less frequently amongst archaeological human remains, and opportunities to analyse such literal examples of the body becoming a form of inscribed text, perhaps reflecting the beliefs or experiences of an individual are extremely rare. The current study is therefore unusual in presenting a suite of investigations conducted on a large section of preserved skin comprising the greater part of the anterior (front) aspect of an individual, in this case bearing numerous tattoos. This substantive portion of the individual's skin had been fixed to a wooden board, apparently to facilitate its display. This 'artefact' was purchased in Paris and currently resides in the care of a private individual who lives in London. As far as the present authors have been able to ascertain, this unusual preparation appears to be unique in Europe. This latter point adds further interest to the question of its date and provenance which were otherwise unknown at the outset of the current study. This project was led by the first author following a request from the skin's current curator to 
investigate it. The work presented here has incorporated opinion and technical input from a broad range of colleagues. Most prominently, the tattoos were catalogued by Smith with input from Slater who also obtained multispectral images under the instruction of Alex Otto (Bournemouth University) as part of an MSc dissertation (Slater 2011). The skin was imaged radiographically by staff at Poole Hospital, Dorset, UK, and examined using infrared spectroscopy by Starkie. Laser scanning and post processing of the respective data were conducted by Manley. The skin was further documented in three dimensions by Smith using Multi View Structure from Motion Photogrammetry (MVSfM), whilst associated hair fibres were analysed by Smith using digital microscopy (also see Acknowledgements re: additional input from other colleagues). Through applying these techniques, we have made progress in visualisation, recording and interpretation of various aspects of this individual's 'dermal remains' and the inscribed words and images represented by the tattoo motifs preserved in his skin, whilst also exploring the extent to which it is possible to construct an individual biography from such evidence.

\section{Background}

\section{From the many to the few: the development of osteobiography}

Charting the history of the wider discipline of biological anthropology is beyond the scope of the current article (for useful accounts, see Buikstra and Beck 2009; Ellison 2018; Little and Sussman 2010). However, a particular point of relevance to the current study is the extent to which publications in the subject have been characterised by fluctuations over time in the scale and focus of published studies. From J.S. Blumenbach (whose thesis on human variations was first published in 1775) to Samuel Morton (1839) and those that followed such as Davis and Thurnam (1865), eighteenth and nineteenth century works commonly viewed individuals simply as representatives of wider populations that could be tracked over time and space through their cranial measurements. By contrast, earlier twentieth century studies were characterised by a greater focus on the remains of single individuals, commonly in the context of recognising evidence for disease in the past. However, rather than indicating a more humanising attitude towards anthropological 'specimens', this trend instead derived from the background of those investigating such remains. At this time, published studies were commonly produced by medical doctors with consequent emphasis on pathological conditions, leading to publications comprised of singular case studies at a time when the basic building blocks of identification and diagnosis of disease-related abnormalities in the skeleton were still being identified (for example: Derry 1913; Keith 1911; Beattie 1930). When such documented cases had become available in increasing numbers, the close of the twentieth century saw a renewed emphasis on population-based studies at the urgence of prominent leaders within the field who advocated the aggregation of anthropological data (with particular emphasis on pathology) to form larger samples in order to ask wider reaching questions about the human past (Ortner 2003; Roberts and Cox 2003; Walker 2000, 2008). However, a simultaneous development emanating initially from North America was the emergence of forensic anthropology, where application of the techniques of biological anthropology within medicolegal frameworks brought a renewed emphasis on the individual, driven by an imperative to identify the otherwise unknown remains of those who had died in tragic circumstances (Isçan 1988). By the early twenty-first century, studies of archaeological human remains focusing on single individuals had become acceptable once again, partly influenced by such developments in the forensic sphere. Grouped under the new term 'osteobiographies', such studies have since received growing recognition as an important and valid line of inquiry whereby questions can be asked and insights gained into wider societies through the entangled and embedded nature of individual human lives within their wider social and physical environments (Agarwal 2016; Knüsel et al. 2010; Melton et al. 2013; Lessa and Guidon 2002; Stodder and Palkovich 2012; Tilley and Oxenham 2011; Tilley and Schrenk 2016). This notion has been eloquently articulated by Gowland $(2015,30)$ who describes the biographies of individuals as 'nested or embedded within the lives of others'. Further, Robb et al. (2019) note the unique value of such studies as offering a 'different kind of history, the history of the body as a locus of appearance and identity'. Osteobiographical studies are also noted as holding particular promise for Marxist and feminist understandings of the past (ibid.) by presenting detailed 'accounts' of the lives of marginalised individuals who are rarely represented in documentary sources. The current article constitutes an example of such a study focused on the remains of a single individual, with this particular case being additionally unusual in relation to both the absence of hard tissues and the presence of a large number of tattooed motifs, which offer the potential to explore facets of this individual's identity and experiences that are normally inaccessible to biological anthropologists.

\section{Bioarchaeological analyses of tattooed skin}

The preservation of soft tissue in human remains generally requires either deliberate anthropogenic intervention or particular types of environmental conditions which inhibit the normal processes of decomposition. Such conditions generally involve extremes of either aridity, cold or moisture and so the majority of depositional environments into which human bodies are placed after death lack the specific qualities 
required for soft tissue to survive. In consequence, opportunities to examine large portions of preserved human skin are very rare in archaeological remains in general and particularly from Europe. With regard to occasions when such evidence survives, various recent studies have demonstrated the potential for visualisation and analysis of preserved tattoos in human remains from archaeological and sometimes forensic contexts. Such researches have considered various questions including the composition of tattooing pigments (Pabst et al. 2009, 2010), methods of enhancing the clarity and visibility of designs (Alvrus et al. 2001; Samadelli et al. 2015; Friedman et al. 2018; Starkie et al. 2011) and the antiquity of tattooing either through the analysis of preserved skin or tattooing artefacts (Deter-Wolf et al. 2016; Gillreath-Brown et al. 2019; Deter-Wolf and Peres 2019). As regards the latter, the practice of puncturing the skin in order to deposit quantities of pigment designed to produce permanent marks with either aesthetic, cultural or medical significance has been shown to date back at least 5000 years (Deter-Wolf et al. 2016; Friedman et al. 2018). Ethnographic, ethnohistoric and archaeological evidence of tattooing from widely dispersed regions further suggest that the practice may have been more widespread throughout much of human history than has previously been acknowledged. Deter-Wolf et al. (2016) provide a useful list of published cases of preserved tattooed skin from different world regions across time, demonstrating the practice to have existed in periods and locations as diverse as Neolithic central Europe (4th Mil. BC); Russia, Egypt and South America (3rd Mil. BC); and Egypt and China (2nd Mil. BC) with further examples from China, Russia, Mongolia, Peru, Egypt, Sudan, Alaska and Mexico (1st Mil. BC). Later, examples demonstrate tattooing to have persisted throughout these regions during the following two millennia (ibid). Various references and artistic depictions from the classical period indicate that tattooing became common throughout the Greek and Roman worlds, having been encountered in Thrace and Persia, and was adopted largely (but not exclusively) as a means of marking slaves and criminals (Jones 1987, 2000; Gustafson 2000). However, notwithstanding sporadic Medieval and Early Modern references to individuals returning from the Holy Land with tattoos they had acquired there (Allen-Rosecrans 2000), the technique appears to have been essentially forgotten in Europe by post-medieval times. Europeans came into contact with various peoples practising tattooing in Africa, Asia and the Americas during the age of colonial expansion (Anderson 2000; Fleming 2000), but the practice was not adopted in any widespread form until it was brought back initially by eighteenth century sailors who had acquired tattoos following contact with indigenous peoples of the Pacific (Thomas et al. 2005).

Whilst a degree of interest has therefore been focused on ancient examples of preserved tattoos from an archaeological point of view, tattooing as a 'modern' phenomenon has tended to receive scholarly attention mostly from social scientists and psychologists, whose interest has been particularly peaked by the rise in popularity of tattoos which occurred from the 1990s onwards in Europe and North America. A further category of academic interest has been the ethnohistoric study of non-western tattooing as encountered during the seventeenth to the nineteenth centuries through European contact particularly with the cultures of East Asia, the Pacific and the Americas (Hage et al. 1996; Thomas et al. 2005; Deter-Wolf and Diaz-Granados 2013). However, notwithstanding some recent exceptions (Angel 2016, 2017; Caplan 2000a), less attention has been given by current scholars to the nature and relevance of tattoos as they then developed in western culture during the nineteenth and earlier twentieth century, not least because it is difficult to gather comparable data. Bradley (2000) describes tattooed individuals as effectively being 'barely visible' from the 'scanty literary sources' available. On one hand, it is not possible to capture systematic qualitative data for these latter periods of the kind gathered for psychological and sociological studies of living people, whilst on the other, as stated, soft tissues rarely survive in buried remains from post-medieval Europe. In this sense, the current study is again unusual in offering an opportunity to obtain information regarding this specific cultural practice from a time when direct evidence in the form of preserved tattoos is seldom encountered.

\section{Monsieur Bonheur}

The example examined by the current study comprises the greater portion of the excised skin of an individual covering the anterior half of the body, including the face and ears (Fig. 1). The skin was stiff, with the feel and texture of dry leather. The piece varied in colour from a light tan colour to very dark brown. The overall size of the individual was consistent with an adult. Biological sex was challenging to determine with certainty. The individual's genitalia were absent, there were no indications of breasts, but also no clear sign of facial hair. The hairline was positioned well back across the top of the forehead consistent with male pattern baldness. In relation to this latter observation, along with the lack of any indications to the contrary, the individual was assessed as most likely to have been male. The limbs and trunk were covered in tattoos, which included both text and images with a particularly prominent motif displaying the word 'Bonheur' (Fr: Happiness) in the region directly above the genitalia (Fig. 2). The provenance of the skin is ultimately unknown. This unusual preparation was purchased by a private collector at an antiques market in Paris and brought to the UK in the early 2000s. The skin has no documented date or provenance, but was claimed by the seller to be that of a murderer, who had been 
Fig. 1 The excised skin of an adult male comprising the greater portion of the skin of the anterior part of the body in coronal section (a), including that of the face and ears (b) with autopsy incisions visible and numerous tattoo markings on the trunk and limbs, dotted lines further illustrate where the skin has been cut (c)
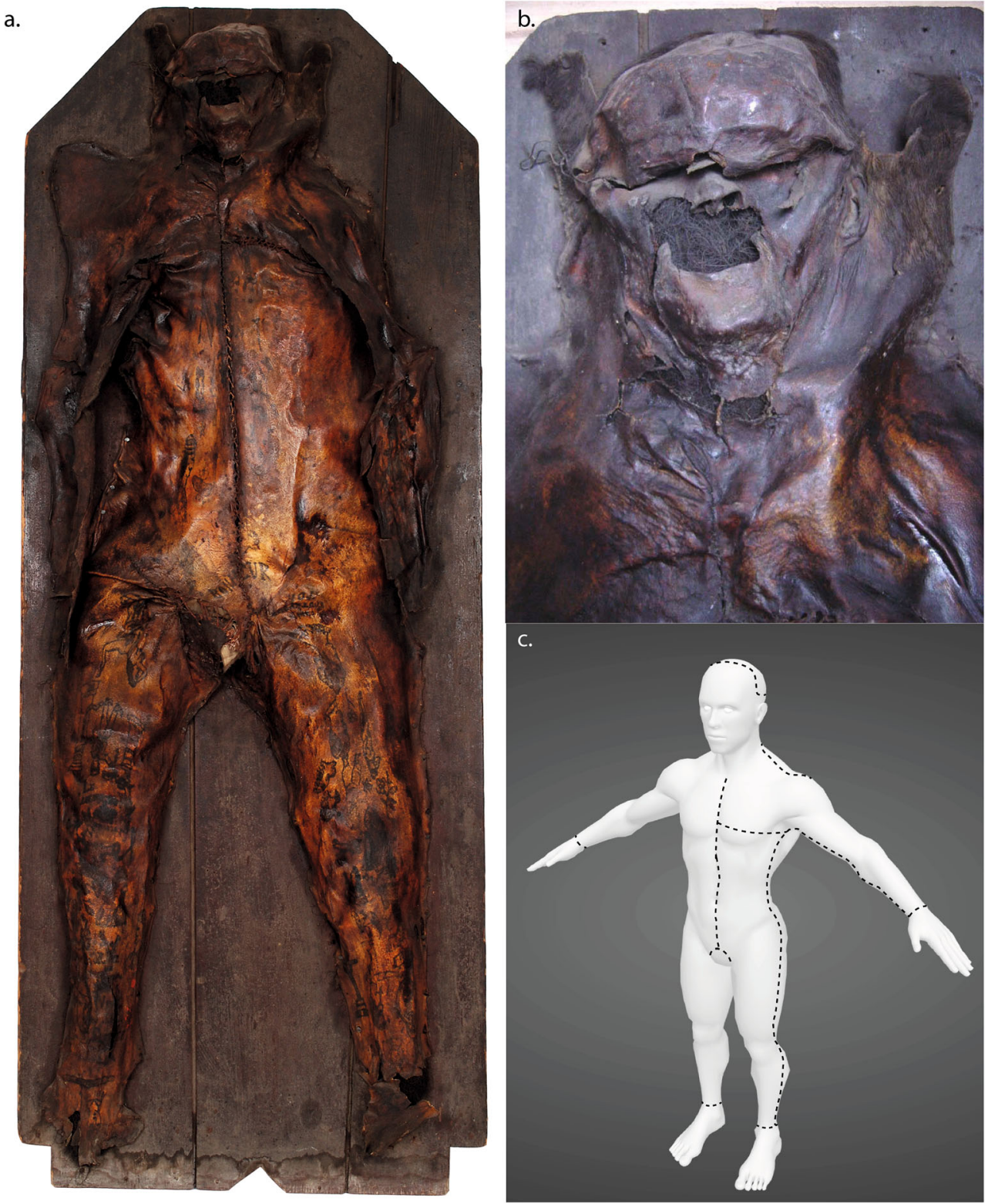

hanged in Marseilles. This story was further embellished with the detail that following execution the man's skin had been removed (presumably by anatomists) and fixed to the door of the court as a warning to others. This story, which is unlikely to contain much (if any) truth, is returned to later in the current article. The purchaser has tended to refer to the skin as 'Monsieur Bonheur' in reference to his most prominent tattoo. This appellation was also adopted by the current researchers, as preferable to a term such as 'the specimen' as the latter presents a dehumanising term that would reduce this man's remains to the status of an object. We therefore mean no disrespect in using the term $\mathrm{M}$. Bonheur, whose identity remains unknown at the time of writing and regard the opportunity we were presented with to study his preserved remains as a unique privilege.

\section{Medical involvement?}

The portion of preserved skin had been excised from the body as two large pieces, effectively representing the body in coronal section (see Fig. 1c). The sectioned portion therefore comprised the skin that had covered the anterior portion of the head, neck, trunk and limbs minus the extremities and genitalia. The removal of this large area of skin in just two portions necessitates a high degree of skill in performing this operation, particularly as regards the skin covering the face and also the ears with the line of the cut diverting around and behind the latter. The skin had also been cut through in the sagittal plane from the groin area to approximately the level of the clavicles, with a further linear cut extending laterally to the left at $90^{\circ}$ from this midpoint section at a level just below the axilla, with 
Fig. 2 Detail of the lower limbs and abdomen showing the extent of variation in colouration of the skin and also giving a sense of the challenges in making sense of the tattoo designs, many of which were difficult to decipher in visible light. The tattoo designs on the torso and upper limbs were all orientated to be upright when viewed by another person, whilst designs on the lower limbs and particularly the thighs were more commonly orientated 'upside down' when in a standing position. These latter would be correctly oriented when viewed by the individual in a sitting position, suggesting he may have tattooed these designs himself

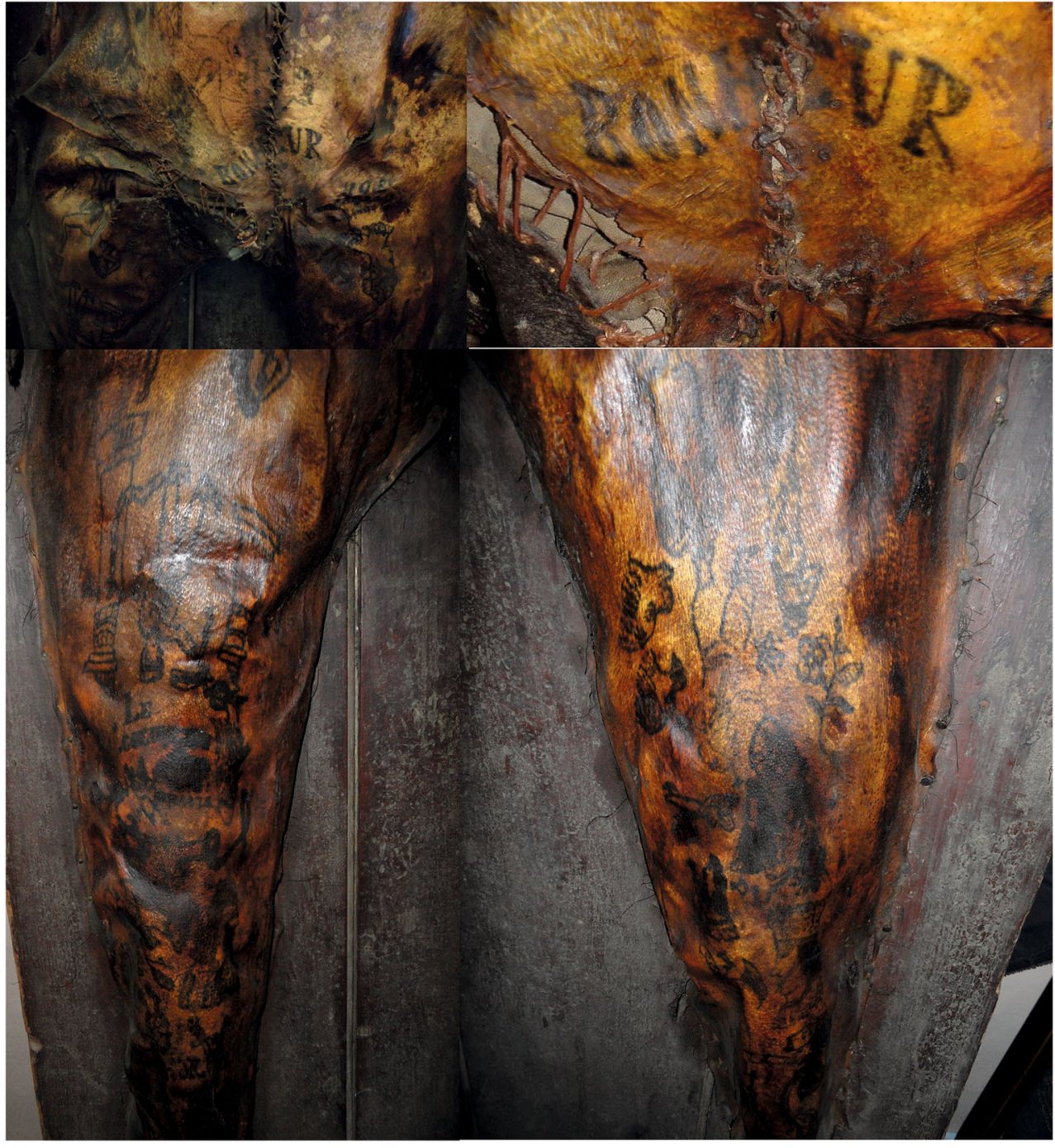

the two cuts forming a T-shape. These latter cuts had the effect of separating the area of skin below the axilla and to the left of the midline. The two portions of skin had then been sewn back together along the lines of these two incisions using a thick thread and a uniform pattern of stitching. This pattern of cutting into the body was recognised by our regional Home Office Pathologist (Basil Purdue) as a style of thoracoabdominal incision used in medical autopsy. Modern autopsies generally employ a Y-shaped or T-shaped incision where linear cuts are made in the region of each shoulder which meet at a point over the sternum, from which a further sagittal cut is then extended down from this point transecting the thorax and abdomen down to the pubic symphysis. The respective flaps formed by these incisions are then reflected back to provide access to the underlying organs and tissues (Finkbeiner et al. 2009). An alternative style of incision involves a single cut down the midline, usually from the level of the laryngeal prominence (Adam's apple). The pattern of incisions on the preserved skin appears to represent a modified version of the latter, perhaps relating to an earlier style of autopsy incision. This suggestion is supported by the form of stitching which follows a pattern in use by pathologists today, known as the 'post-mortem stitch' and used to draw the edges of the skin back together after autopsy in order to make the body more presentable for relatives etc. (B. Purdue, pers. comm.). The salient point with regard to $\mathrm{M}$. Bonheur is that these features suggest the skin to have been removed and at least initially dealt with, by one or more individuals with medical skill.

\section{Mounting for display}

The skin was fixed to a wooden board measuring $1.77 \times 0.69$ $\mathrm{m}$, by short, flat-headed nails which were roughly evenly spaced every few inches around its outer circumference, with the exception of the skin of the upper limbs which were only nailed along their lateral margin. The skin had also been stuffed with fibres later identified as horse hair (max. diam. $187 \mu \mathrm{m}$ measured using a Keyence VHX-5000 digital 
microscope), which were visible through areas where the skin was damaged. This stuffing material therefore had the effect of presenting the skin as a three-dimensional form in relief, rather than a flat two-dimensional preparation. The board was formed of three tongue and grooved planks, fixed by supporting crosspieces on the reverse and appeared to have been made specifically (with limited carpentry skill) to mount the skin, rather than being part of a wooden object adapted for the purpose, such as a door or table top. There was damage to the skin in the area of the groin which had been patched with a piece of leather, with a piece of cloth stuffed underneath. Further damage to the area of the throat had been similarly stitched in apparent attempt to repair it. The style and quality of stitching over these repairs was far inferior to the careful, consistent style of stitch holding the autopsy incisions together. Overall, the manner in which the skin was mounted was consistent with an intention to put this preparation on display, although the crude manner in which it had been effected was inconsistent with the care and style that would be normal for a medical/anatomical preparation, instead indicating a lack of skill in the execution.

\section{The tattoos}

The observable tattoo markings were initially assessed to comprise between 55 and 60 separate motifs, although this figure was difficult to define as some motifs were more easily discerned than others and it was not always possible to tell whether groups of tattoo markings represented parts of the same image or separate images positioned close together. The motifs were drawn in outline using a black or darkcoloured pigment. Some areas were shaded with the same pigment whilst a small number of motifs exhibited areas of reddish-coloured shading. The aforementioned variations in colour across the skin are consistent with normal changes that occur post-mortem (Starkie et al. 2011). In some areas where the skin was darker due to such postmortem discolouration, it was clear that tattoos were present although the nature of the designs was often difficult to discern. This issue was exacerbated in some areas, and particularly on the upper limbs by the degree of distortion the skin had undergone, making the respective tattoo motifs effectively 'unreadable'. In several areas where the skin had taken on a particularly dark shade, it was not possible to tell in normal light whether tattoos were present or not.

\section{Initial questions}

In being presented with an opportunity to investigate this highly unusual but effectively unprovenanced preparation, a range of initial questions was apparent. Whilst all human remains are unique, M. Bonheur represents a particularly uncommon survival and so non-destructive techniques were preferred wherever possible. With regard to the nature of this man's remains, it was unclear whether skin and hair were the only tissues involved or whether other body parts such as bone or preserved organs might also be present underlying the skin. In this sense, it was also unclear exactly how this 'artefact' had been created. Many of the tattoo motifs were indistinct and difficult to make sense of, whilst as mentioned, parts of the skin were too dark to discern whether tattoos were even present. It was therefore clear that further exploration was needed using other optical techniques to enhance and clarify the tattoo markings. Nothing was known regarding the dates when this man had lived and died or his geographic origin, whilst arguably the most significant question was why his remains had been treated in this unusual manner after death? On a wider level, the prospect of examining M. Bonheur's tattoos offered a more general opportunity to consider the extent and type of information that can be obtained regarding the life of an otherwise unknown individual through the analysis of this very specific cultural practice. Lastly, consideration was given to how such an 'artefact' might best be preserved by record as it is currently curated privately and might never be accessioned by a museum or other public institution.

\section{Analyses and results}

The following section details a fairly diverse range of methods that were applied in the current investigation. In this regard, we deviate from a traditional scientific article structure by presenting the respective results directly after each method in order to make this material easier to follow.

\section{Computerised tomography}

The questions of how the overall preparation of skin and board had been constructed in addition to the query over whether other tissues might be present were addressed using computerised tomography. M. Bonheur was passed through a Phillips Big Bore Brilliance CT Scanner in the Department of Radiography at Poole Hospital, Dorset, UK. This instrument was selected firstly because of its facility to scan particularly large patients, therefore accommodating the board, and secondly for its ability to differentiate between objects of very similar density, as was the case with the skin and hair present in the current case. The resultant volumetric data were viewed both as sequential slices and as a rendered three-dimensional visualisation.

\section{Results}

The CT scan data were illuminating in revealing that no other tissues or additional materials were present beneath the preserved skin, other than the horse hair stuffing, 
already visible through damaged areas (Fig. 3). This result was contrary to expectations as it seemed counter-intuitive that the skin alone could hold the shape of the body independently and we had previously speculated that some supporting structure, whether artificial or involving parts of the skeleton might be present underneath. In fact, the dried skin was notably stiff and in fact so much so that it required no further support to maintain the outward contour of the body approximating its shape in life.

\section{Multispectral photography}

Multispectral light sources commonly used for enhancing the appearance of biological evidence at crime scenes (Lee and Khoo 2010) were utilised in efforts to enhance the degree of contrast visible between the tattoo motifs and the surrounding skin. This technique makes use of a powerful light source containing the ultra violet, visible and infrared components of the light spectrum. Filters are then applied to reduce the reflected light to specific bandwidths corresponding to particular colours. The light is either more strongly reflected or absorbed according to the nature of the target with different colours of light penetrating to differing depths. The resulting effect can cause the evidence either to fluoresce or to appear in increased contrast. Various coloured light sources and filters were applied (using Foster and Freeman Crime-Lite 2 forensic light sources) in order to find which produced the greatest degree of contrast between the dark pigment of the tattoo motifs and the surrounding skin.

\section{Results}

Of the various combinations of light source and filter colours applied (Fig. 4), the best results were achieved using a blue/ green light source $(468-526 \mathrm{~nm})$ with an orange filter (497 $\mathrm{nm})$. Other combinations achieved varying results with the lowest levels of contrast achieved with an ultraviolet light source and pale-yellow filter. In this case, the blue/green light had worked best in causing the unmarked areas of skin to faintly fluoresce. Fluorescent light is re-emitted (rather than reflected) light which occurs at a longer wavelength than the original incident light. In the case of blue light, re-emitted fluorescence generally falls in the orange spectrum; hence; the best results in this case were obtained using an orange filter, whilst the very dark pigments of the tattoos tended to absorb light in general resulting in a high degree of contrast. This technique therefore served to clarify a number of motifs and details which were otherwise difficult to make sense of (Fig. 5), although the portions of skin that had been subject to the greatest amount of postmortem discolouration remained impervious to this method, continuing to appear simply as dark patches.

\section{Infrared reflectography}

Infrared reflectography (IRR) is a well-documented technique used in the forensic examination of artwork and documents. The infrared spectrum lies on the opposite edge of the visible light spectrum from ultraviolet wavelengths. As infrared wavelengths are longer than those that make up the visible

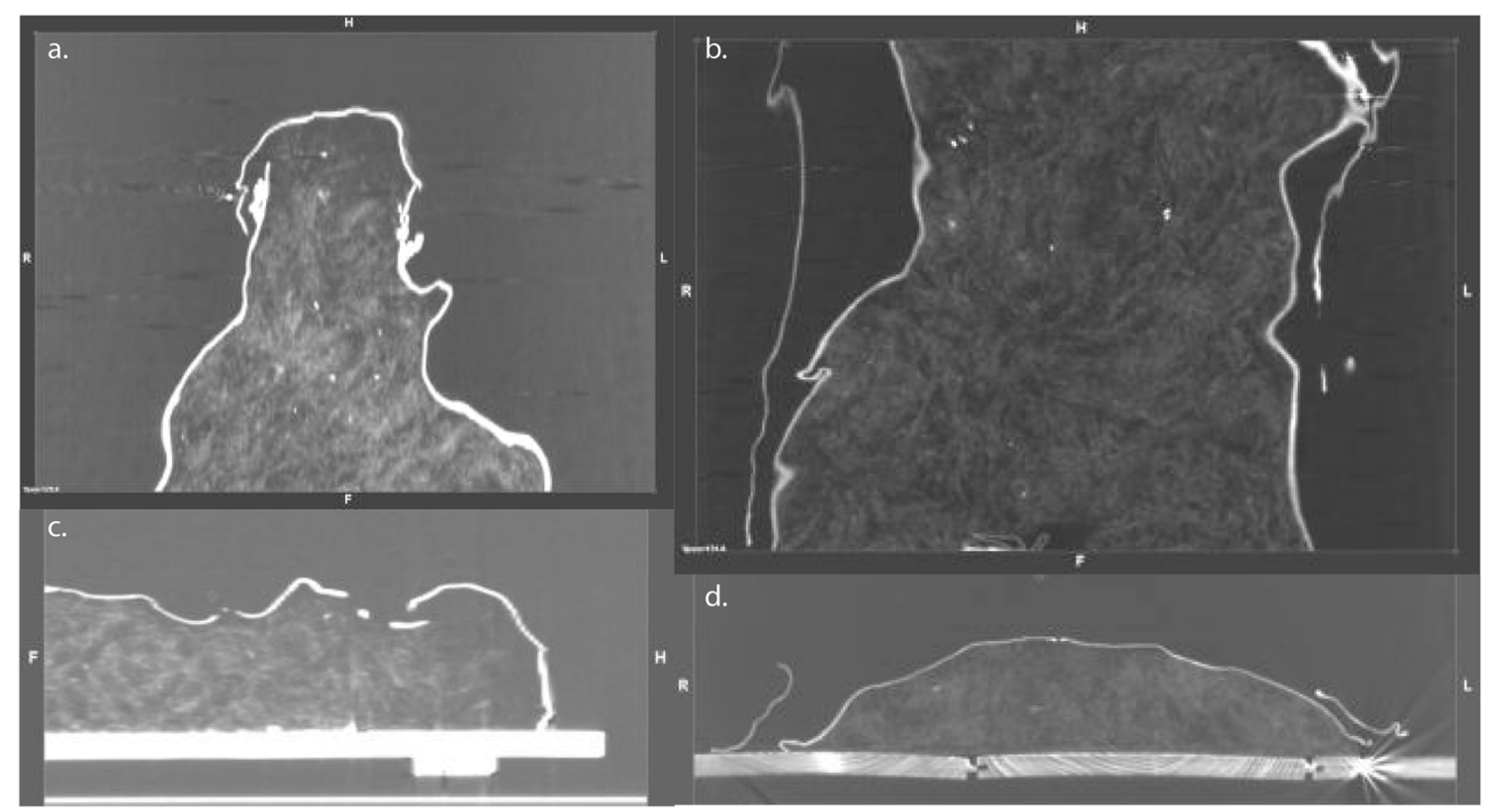

Fig. 3 Views through the skin and board obtained as slices using computerised tomography, (a, c) sagittal and coronal slices through the head; (b, d) axial and coronal slices through the abdominal region. It was anticipated that the preparation might include other soft tissues or bone; however, this radiographic imaging revealed only horse hair stuffing beneath the skin 


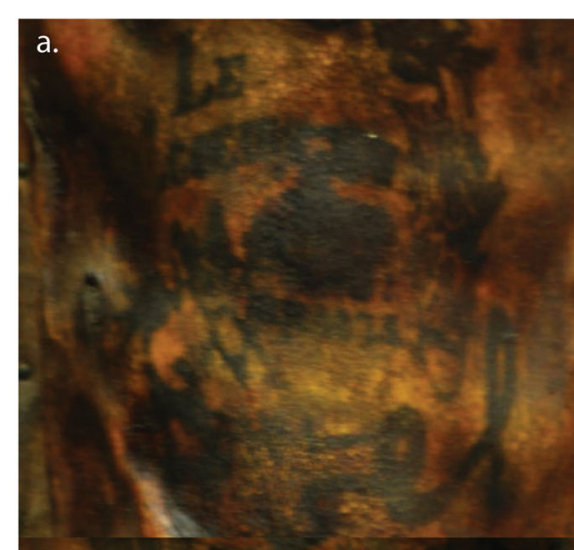

c.

b.

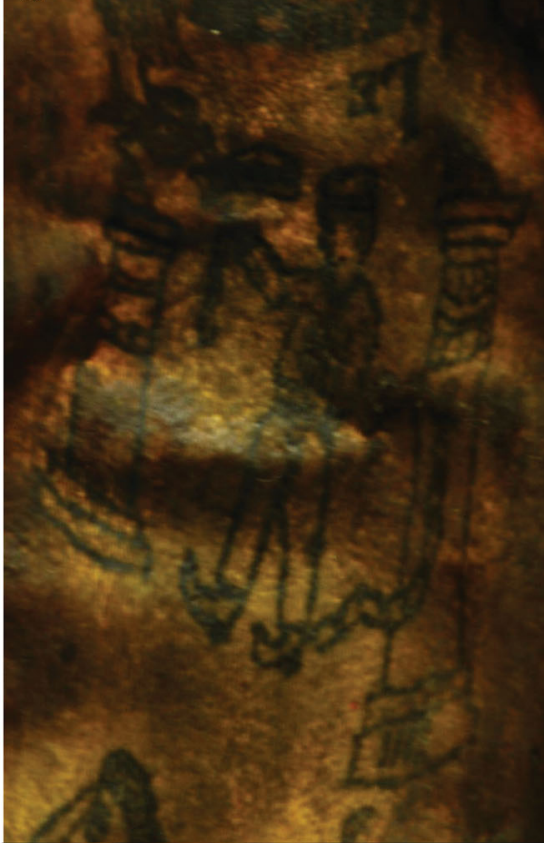

e.

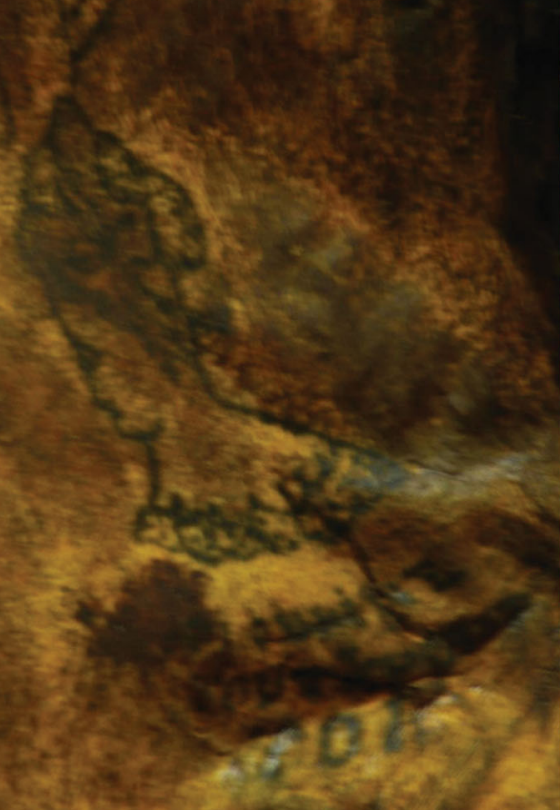

d.
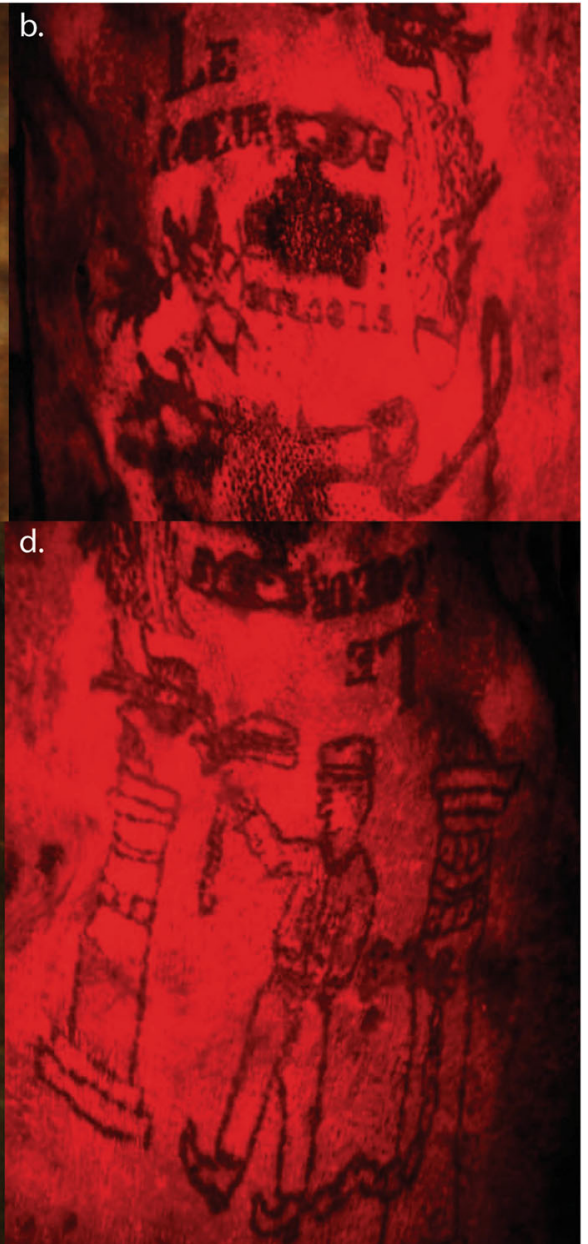

f.

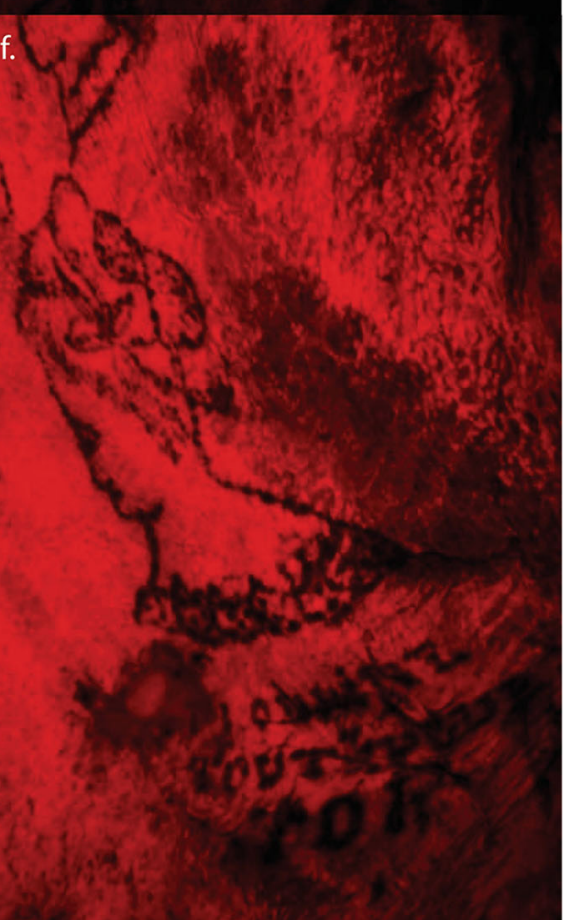


Fig. 4 Examples of tattoo motifs with enhancement under multispectral lights and filters, a, b illustrating clarification of text 'Le coeur' to the right of which are two clasped hands, whilst below the text is a heart pierced by arrows; c, d the enigmatic image of a uniformed figure, chained to a pillar; e, $\mathbf{f}$ the image of a woman that appears to be a portrait of a specific individual, rather than a generic motif

light spectrum, materials that appear opaque in visible light may become transparent due to the different penetration capabilities of materials at different wavelengths. This quality is dictated by chromophores, the part of a molecule responsible for its colour by absorbing light at differing wavelengths (IUPAC 2014). Therefore, by examining documents or paintings, using IRR, it is possible to see below the images visible with the naked eye, to any 'hidden' or obscured information such as charcoal underdrawings beneath classical paintings, or 'doctoring' of original documents in cases of fraud. This technique offers particular potential in the case of tattooed skin as the reason tattooing works at all is that the particles of pigment are held below the surface at the epidermal/dermal junction (Sperry 1992). The penetrative power of infrared light therefore offers opportunities to bypass areas of staining or discolouration at the outer epidermal surface to produce enhanced views of the patterning of pigment underneath (Starkie et al. 2011). Views of the skin were captured both as still images and video using a Sony Handycam DCR/RW with built-in 'night vision' system comprising active illumination and NIR range of $700-1,000 \mathrm{um}$. This equipment had previously proved effective in imaging experimental tattoos (Starkie et al. 2011).

\section{Results}

IRR proved particularly useful in penetrating areas of discolouration on the skin surface through to the

\begin{tabular}{|c|c|c|c|}
\hline Combination & Light source & Filter & Result \\
\hline 1 & Ultraviolet & V. pale yellow & Low Contrast \\
\hline 2 & Violet & Pale yellow & Low Contrast \\
\hline 3 & Blue & Yellow & Slight enhancement \\
\hline 4 & Blue/Green & Orange & Strong enhancement \\
\hline 5 & Green & Orange & Slight enhancement \\
\hline 6 & Green/Yellow & Red & Slight enhancement \\
\hline
\end{tabular}

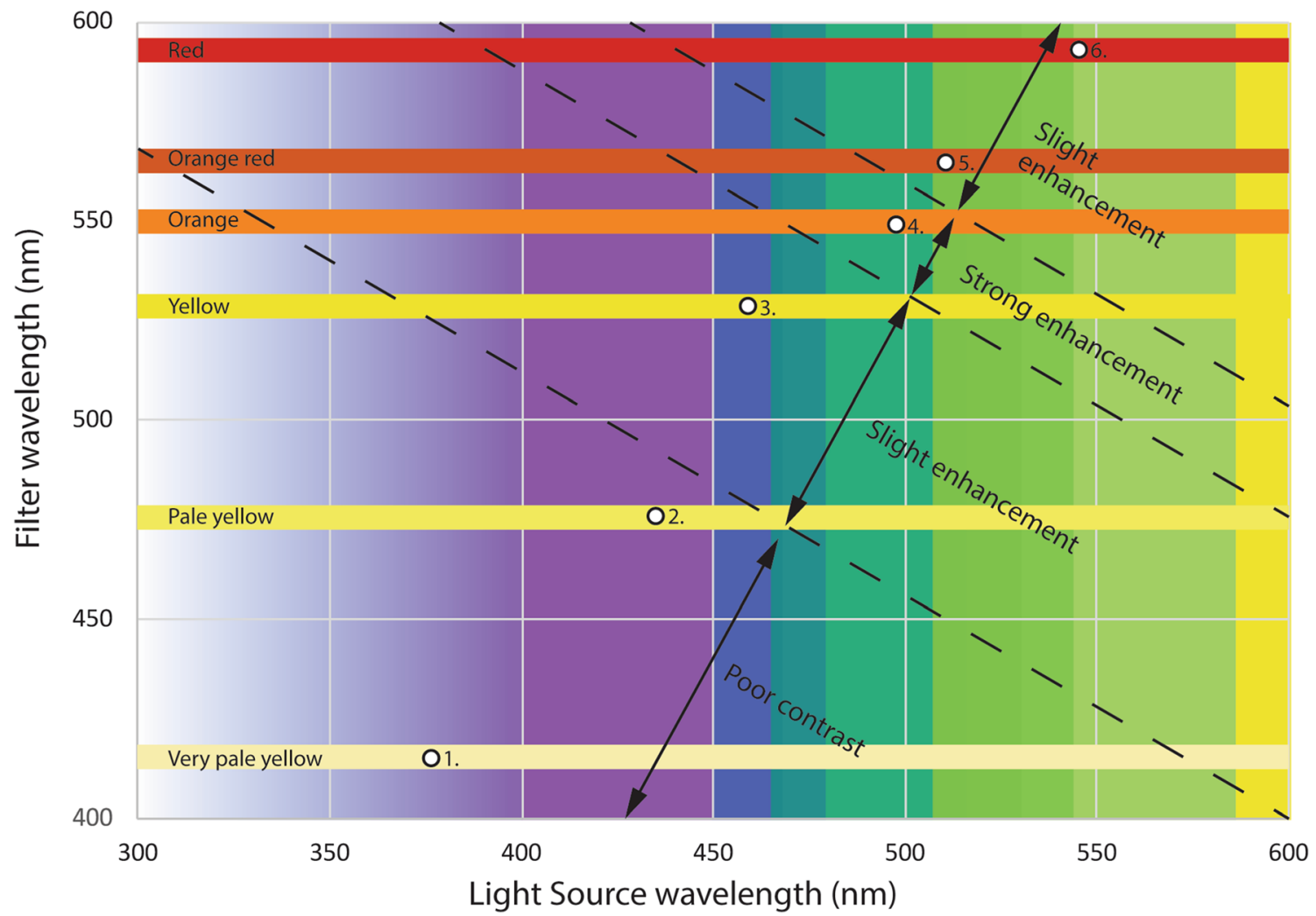

Fig. 5 Relative values and results of examination of the tattoos using different colour frequencies of light and filters 
unblemished tissue beneath, whilst again the tattoo pigments were more light absorbent. In consequence, the resultant images had significantly improved levels of clarity and contrast, with greater consistency across the motifs overall, exceeding the improvements already achieved by filtered UV light (Fig. 6). The technique also made it possible to see through areas of severe discolouration to the tattooed images behind, revealing images and text in areas where tattoos were not previously visible. Consequent to these further results, Table 1 lists the full range of tattooed images and text apparent.

\section{Laser scanning}

Whilst standard photography offers an overall visual record of an object, it is challenging to take accurate measurements from such images, whilst physically measuring a complex and ultimately fragile sample such as $M$. Bonheur presents practical challenges of its own. As a possible solution to the issue of three-dimensional (3D) preservation by record, $\mathrm{M}$. Bonheur was recorded using a Konica Minolta VIVID 900 laser scanner. A total of 51 scans (23 of the front and 29 of the rear) were stitched together to produce a single wire mesh model, onto which photographs taken by the scanner were overlaid.

\section{Results}

The resultant 3D model (Fig. 7) permitted accurate linear measurements of the skin (Table 2), but suffered from limitations as a method of visualisation. The complex nature of the form taken by the skin meant that even using this large number of scans it was impossible to avoid areas of 'shadowing' where the laser beam was obscured and no data were recorded. Whilst this issue could of course be remedied by using an even greater number of scans taken from different positions, successfully eliminating all areas of shadowing on such a complex target would be highly labour-intensive and timeconsuming. It was therefore concluded that whilst this technique is desirable for its ability to record sufficiently comprehensive point cloud data to allow accurate measurements to be taken, laser scanning is not the best solution currently available for detailed three-dimensional visualisation of intricate objects.

\section{Photogrammetry}

As an alternative means of preservation by record in three dimensions, the skin of M. Bonheur was modelled using Multi-View Stereo Structure from Motion (MVS-SfM) photogrammetry. This technique employs geometric principles to model the relative spatial positions of surface points in a set of overlapping photographic images of a single target. Modern photogrammetric software employs automated processes to generate a $3 \mathrm{D}$ point cloud, which is used to construct a wire mesh that is then textured and overlaid with stitched image data from the source photographs. Data were captured from M. Bonheur as a series of 159 overlapping photographs taken with a $16 \mathrm{mp}$ Canon Powershot camera in normal daylight. Markers were added to the wooden board to which M. Bonheur's skin was fixed, in order to act as control points during the image processing and aid consistency of calculated measurements. The images were processed using the Agisoft Photoscan Professional software package.

\section{Results}

This method produced a three-dimensional model based on a point cloud consisting of 20,213 tie points and 23,722 polygon faces (Fig. 8). An interactive 3D pdf. version of this model has been supplied as online supplementary material to the current article in order to further aid visualisation.

\section{Dating}

The general style of the tattoo motifs is analogous to published examples dating from the later nineteenth and beginning of the twentieth century (Lombroso 1876-1897, Lacassagne 1881, Bertillon 1885, Angel 2015, 2016, 2017). Some of the tattoos are obviously 'hand-poked', a relatively slow process where simple images were scratched or 'pricked' into the skin using pigment-dipped needles in a naïve style that implies the work of an amateur. This conclusion was reached as the tattoos exhibit 'blooming' of ink, along with irregular linework. These characteristics differ from the smooth, regularity produced by electric tattoo machines, instead being more commonly seen in cultures which employ 'hand-poking' styles where the needle, thorn or other application device is dipped in pigment before being scratched or 'pricked' into the skin. Some of the tattoo motifs did appear more fluid and complex in design. This could indicate the use of an electric tattoo machine. However, these were invented by Samuel O'Reilly in

Fig. 6 Tattooed images and text clarified using infrared reflectography. a 'Vive la Flotte', b crossed swords overlaid with the words 'Mort aux Commissaires', c 'Flourine Je T'Aime' where the J appears to be reversed possibly indicating the individual had tattooed this himself, $\mathbf{d}$ 'Flourine Tout Pour Toi' - this text appears beneath the head and shoulders portrait of a woman shown in Fig. 4 e, e hand holding a flower, f anthropomorphic crescent moon, g. monumental cross (left), with a human figure orientated the other way up (right), $\mathbf{h}$ detail of the chained man reaching up to a bird, the object in its beak was more discernible on moving the camera across the image and was revealed to be a scroll bearing the word 'Liberté', i detail from the base of the pillar to which the man is chained by his leg, with the numbers ' 1883 ' visible 


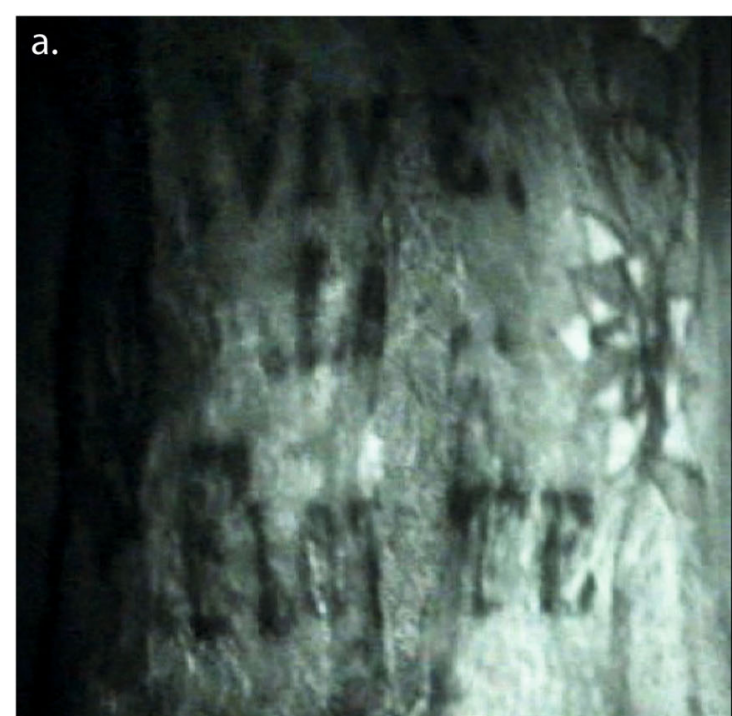

b.

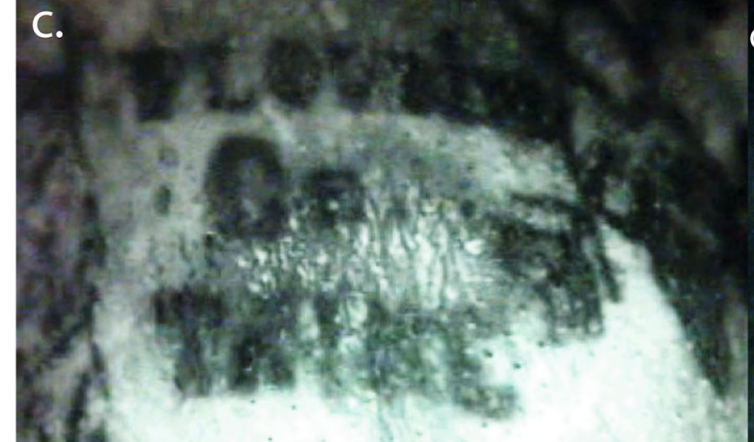

d.
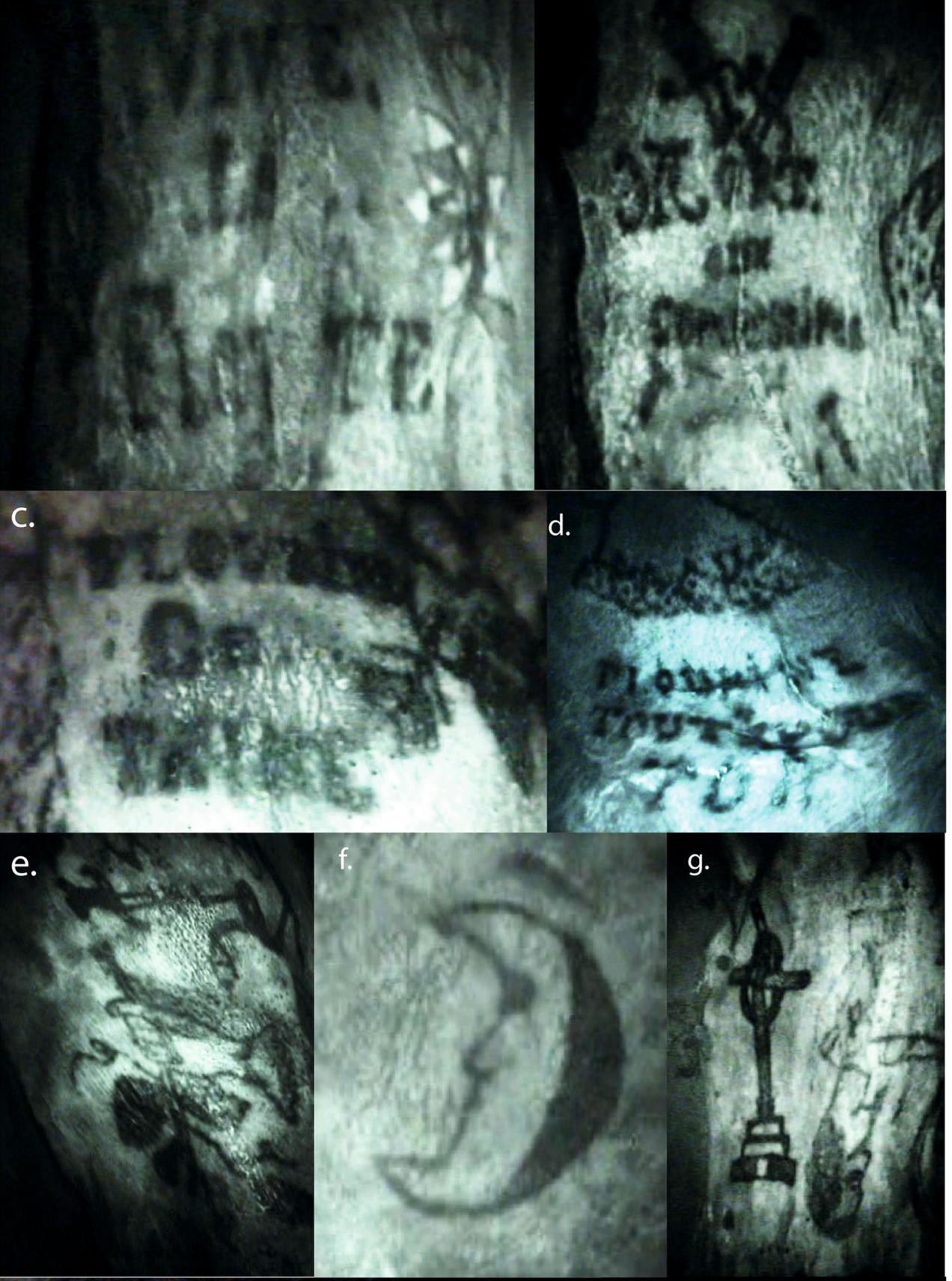

h.

i.

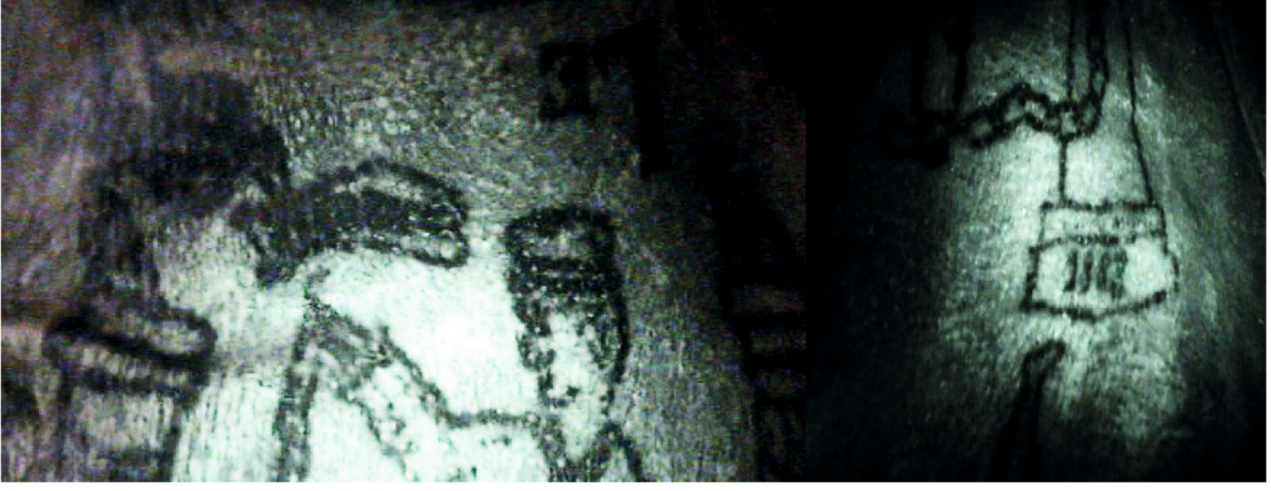


Table 1 Individual tattoo motifs observed following enhancement with multispectral and infrared imaging methods

\begin{tabular}{|c|c|c|c|c|}
\hline Number & Location & Image & Text & Orientation \\
\hline 1 & Right arm & Anchor & & Up \\
\hline 2 & Left thigh & Zoomorphic beaked face & & Down \\
\hline 3 & Lower abdomen & & 'Bonheur' & $\mathrm{Up}$ \\
\hline 4 & Left lower leg & 'Celtic' style cross & & Up \\
\hline 5 & Right thigh & Chained man & 'Liberté'; '1883’ & Down \\
\hline 6 & Left arm & Circus clown, pointed hat & & Up \\
\hline 7 & Right thigh & Clasped hands & & Down \\
\hline 8 & Central abdomen & Crescent moon, 3 stars & & Up \\
\hline 9 & Right upper arm/ axilla area & Crescent moon, face & & $\mathrm{Up}$ \\
\hline 10 & Left arm & Crossed Swords & & $\mathrm{Up}$ \\
\hline 11 & Right knee & Crossed swords/daggers & 'Mort aux Commissaires' & Up \\
\hline 12 & Right ankle & Elongated object (indistinct) & & Unclear \\
\hline 13 & Left knee & Elongated object (indistinct) & & Up \\
\hline 14 & Top Left thigh & Female figure & 'Flourine tout pour toi' & Down \\
\hline 15 & Left arm & Female figure, pointed hat & & $\mathrm{Up}$ \\
\hline 16 & Left thigh & Female nude & & Down \\
\hline 17 & Left Forearm & Female nude & & $\mathrm{Up}$ \\
\hline 18 & Right lower leg & Female nude with snake & & $\mathrm{Up}$ \\
\hline 19 & Central chest & Figure (?Female) & & $\mathrm{Up}$ \\
\hline 20 & Right leg & Figure, gender undetermined & & Up \\
\hline 21 & Right lower leg & Figure, gender undetermined & & Up \\
\hline 22 & R. Chest & Figure, gender undetermined & & $\mathrm{Up}$ \\
\hline 23 & Right ankle & Figure, gender undetermined & & Down \\
\hline 24 & Left leg & (?)Female figure (indistinct) & & $? \mathrm{Up}$ \\
\hline 25 & Right side of chest & Flag & & $\mathrm{Up}$ \\
\hline 26 & Central chest/ abdomen & Floral motif & & $? \mathrm{Up}$ \\
\hline 27 & Left leg & Floral motif & & ?Up \\
\hline 28 & Left leg & Floral motif & & $? \mathrm{Up}$ \\
\hline 29 & Central chest & Floral motif & & $? \mathrm{Up}$ \\
\hline 30 & Right Thigh & & 'Flourine Je t'aime' & Down \\
\hline 31 & Left thigh & Flower & & Down \\
\hline 32 & Right chest & Flower & & $? \mathrm{Up}$ \\
\hline 33 & Right arm & Flower?/star? & & $? \mathrm{Up}$ \\
\hline 34 & Left leg & Figure, gender undetermined & & $? \mathrm{Up}$ \\
\hline 35 & Left arm & Hand holding (?)flower & & Up \\
\hline 36 & Right Thigh & Hand holding flower & & Down \\
\hline 37 & Right thigh & Heart pierced with sword and arrow & 'Le Coeur' & Up \\
\hline 38 & Left arm & (Burning?) Heart pierced with daggers/swords & & Up \\
\hline 39 & Right side of chest & Indeterminate & & Unclear \\
\hline 40 & Left leg & Long haired figure with sword piercing chest & & Up \\
\hline 41 & Left arm & Male figure & & Up \\
\hline 42 & Right thigh & Male figure-(?)Arab head dress & & Down \\
\hline 43 & Left lower leg & Male figure crown & & Up \\
\hline 44 & Right arm & Male figure Fez & & Up \\
\hline 45 & Right forearm & Male figure kepi & & Up \\
\hline 46 & Right abdomen & Male figure turban & & Up \\
\hline 47 & Left thigh & Male figure turban, pantaloons & & Down \\
\hline 48 & Left lower leg & ? Male figure & & Down \\
\hline 49 & Top Right Thigh & Nude couple, sexual position & & Down \\
\hline
\end{tabular}


Table 1 (continued)

\begin{tabular}{|c|c|c|c|c|}
\hline Number & Location & Image & Text & Orientation \\
\hline 50 & Left arm & ? Rooster & & $\mathrm{Up}$ \\
\hline 51 & Central abdomen & Seated figure, gender undetermined & & $90^{\circ}$ to midline of body* \\
\hline 52 & Left thigh & Short haired figure (?male) & & Down \\
\hline 53 & Left leg & (?)Skull with gravestone & (?) ' $18 \ldots . \mathrm{RIP}$ ' & $? \mathrm{Up}$ \\
\hline 54 & Right leg & Snake & & Unclear \\
\hline 55 & Left lower leg & Snake(?) & & Unclear \\
\hline 56 & Left side of chest & Sword/dagger piercing skin & & Up \\
\hline 57 & Right thigh & Sword/dagger piercing skin & & $90^{\circ}$ to midline of body $* *$ \\
\hline 58 & Right lower leg & & 'Vive La Flotte' & Up \\
\hline 59 & Left thigh & Zoomorphic face, profile & & Down \\
\hline 60 & Left arm & & 'Amis Des .....' & Up \\
\hline
\end{tabular}

*Top of image to left; **sword hilt to the right

1891 (Angel 2016), but were not commonplace for several decades, until electricity was widespread. Consequently, it seems more likely that these better executed tattoos were applied by an expert hand-either a professional tattooist, or at least someone well-practised in this art. A mid to late nineteenth century date was proposed on this basis. This was further supported when the IRR unveiled a previously hidden detail, in the rather enigmatic scene of a uniformed man shackled by his left ankle to a column (Fig. 5c, d and Fig. 6h, i). The man's right arm, bearing a broken shackle chain, was stretched up, to a bird flying down, carrying a scroll in its beak. The IRR revealed the scroll to bear the word 'Liberté' (Fr: freedom) whilst four indistinct marks at the base of the column were revealed to be numerals reading
Fig. 7 Three-dimensional virtual model produced using point cloud data captured by laser scanning (Konika Minolta VIVID 900).

The model is a composite stitched together from 23 individual scans (front view) and 29 scans (rear view) with photographs captured by the scanner then overlaid (right). This method of threedimensional preservation by record was useful in permitting accurate measurements but was labour-intensive and failed to capture the complete surface with areas omitted where the laser beam was 'shadowed' across the surface

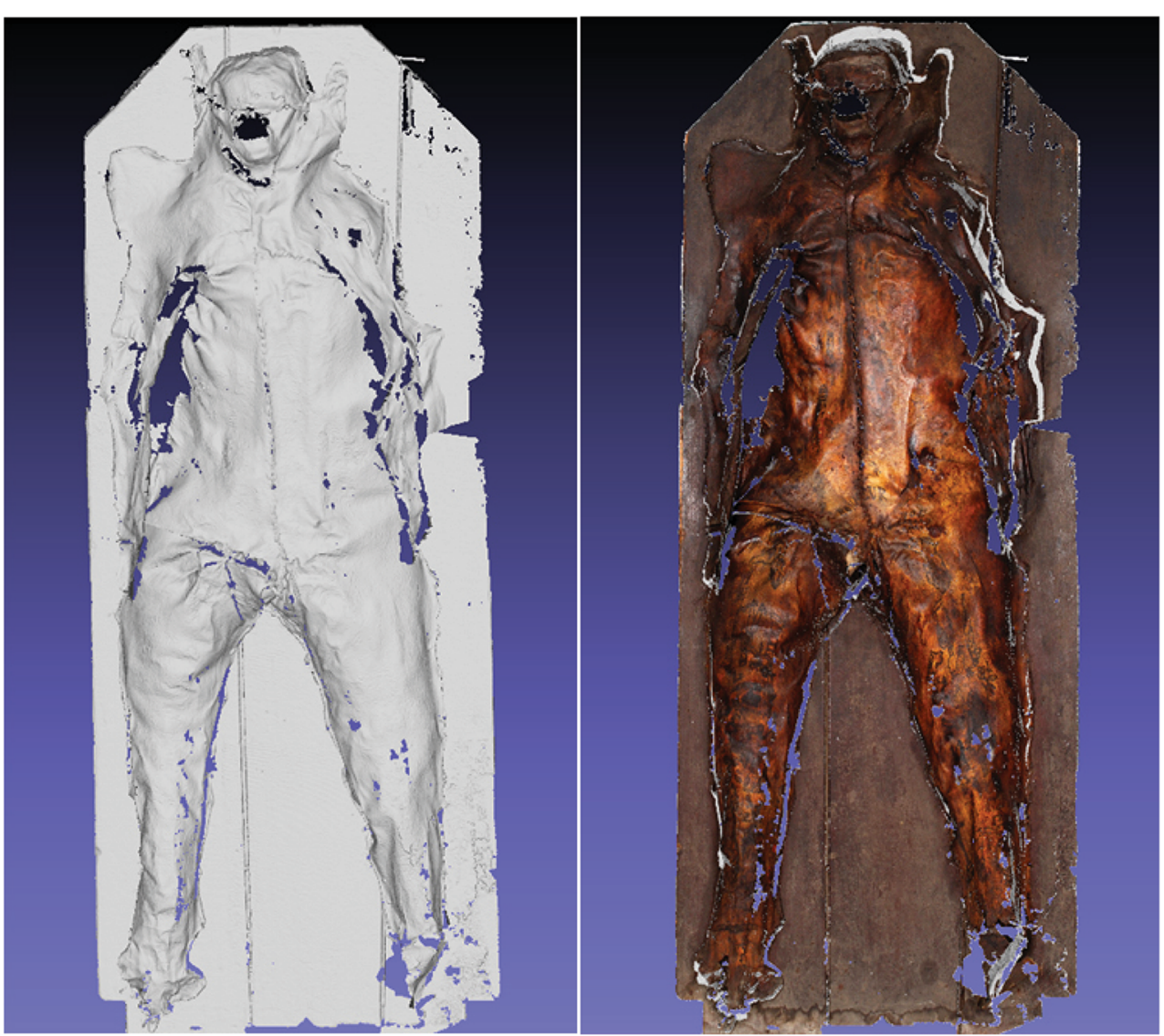


Table 2 Dimensions of the skin as measured from laser scan data

\begin{tabular}{ll}
\hline Measurement & Result (m.) \\
\hline Max. length & 1.69 \\
Max. width (hip area) & 0.54 \\
Max. width upper thigh & 0.18 \\
Torso max. length & 0.75 \\
Head max. sagittal length & 0.21 \\
Head max. width & 0.18 \\
\hline
\end{tabular}

'1883'. Possible meanings of this apparent date are discussed later, although it would seem reasonable to interpret this as consistent with the suggestion that $\mathrm{M}$. Bonheur was alive during the later nineteenth century.

With regard to scientific dating, there were good prospects for dating the skin using radiocarbon. However, the standard error inherent in ${ }^{14} \mathrm{C}$ AMS dating would mean that this would be unlikely to offer a date range narrower than AD 1700-1950 (F. Petchey-pers. comm) and so would not move the project forward. As an alternative, a sample of wood from the board that the skin was fixed to was dated using Fourier transform infrared spectroscopy (FTIR). When infrared radiation strikes an organic molecule, the molecular bonds absorb the energy and respond by vibrating, with different molecules vibrating in response to different frequencies of infrared light. The pattern of responses is therefore specific to a particular material, with changes in the substance causing corresponding variation in the spectrum of responses. One source of such variation is the denaturing of molecules as a material ages and decays. This effect permits assessment of the age of a given sample of a material through comparison with samples of known age. With regard to wooden objects, this technique has been used successfully in the detection of modern art forgeries, commonly producing results that are accurate to \pm 10 years in samples $<450$ years old (Matthaes 2002).

Samples were extracted from the wood according to the protocol of the Museo d'Arte e Scienza, Milan, where the FTIR analysis was carried out. A hole 3-6 $\mathrm{mm}$ in depth was drilled using a 3-mm drill, with the wood dust discarded. The hole was then extended a further 4-6 mm using a clean drill bit, the dust collected in a folded paper 'Beecham's wrap', which was sealed with tape and placed inside a sample bag. This process was repeated twice to give three samples. The samples were inspected for impurities and then pressed and embedded into discs for analysis. The results were compared to the museum's database of historic wood samples, to give a type and age for the samples.

\section{Results}

The spectra produced by the FTIR analysis of the wood samples were consistent with coniferous wood (most likely pine). The dating result with the lowest error range gave an age of $150 \pm 15$ years, which equated to a date between 1846 and 1876. Of course this range dates the board, rather than dating the skin directly, instead providing a terminus post quem for the point when the skin was mounted.

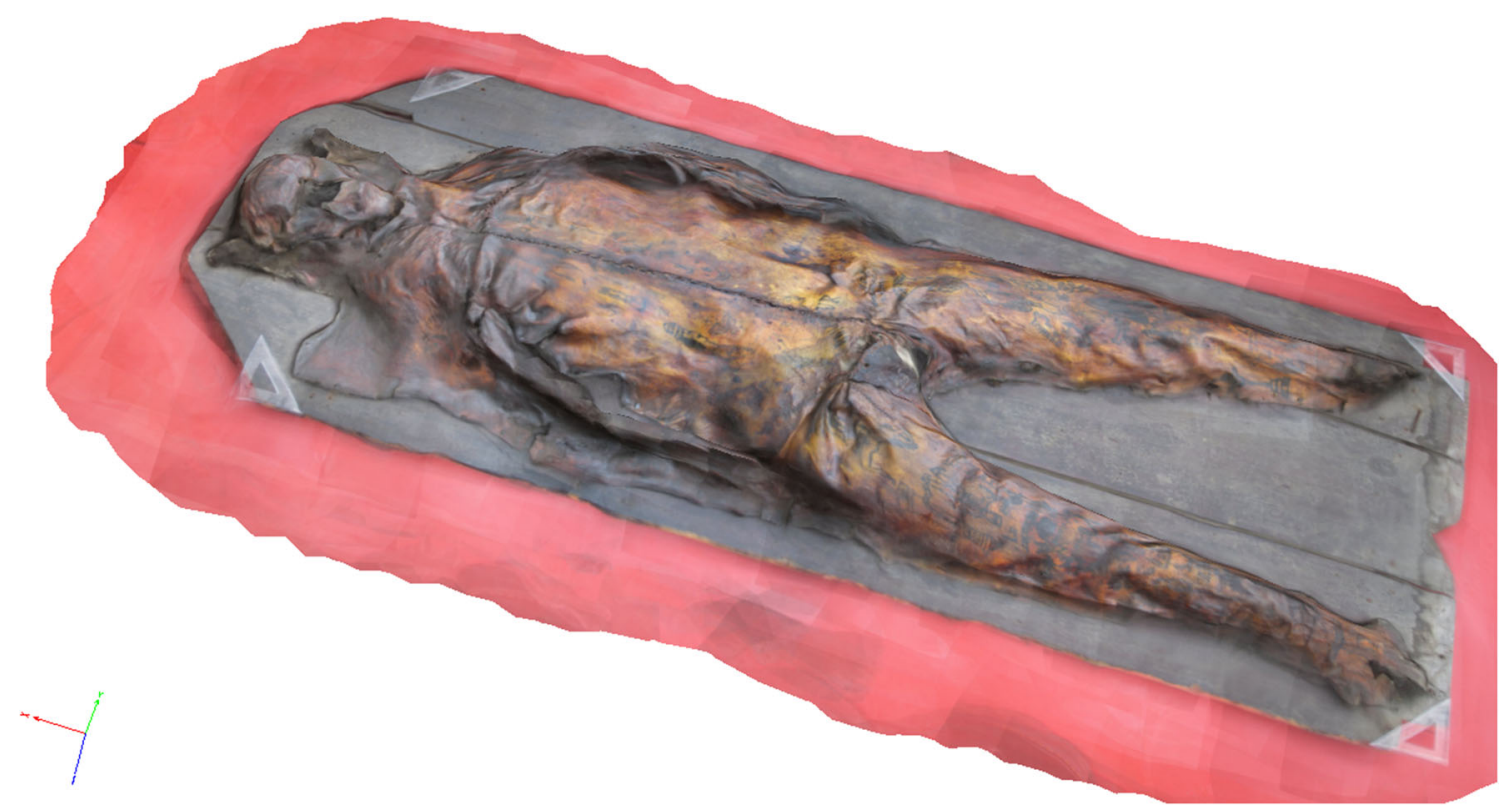

Fig. 8 Three-dimensional virtual model produced using point cloud data captured by multi-view structure from motion (MVSfM). This model comprises a surface mesh interpolated from 159 overlapping photographs, with 23,722 faces and 12,002 vertices, the triangular shapes in the corners are control points added to increase the accuracy of the model (interactive 3D pdf version of model supplied as online supplementary material) 


\section{The tattoo motifs}

The opportunity to view and catalogue the many tattooed motifs on this individual's skin represents a rare opportunity to gain unique insights from a form of cultural modification that comprises the 'embodiment of social relations' (Bradley 2000). However, such an endeavour is far from simple. Even determining the precise number of tattoo motifs presented a challenge, due to the indistinctness of many of the images. This issue was exacerbated by the degree of distortion that had occurred due to shrinkage, stretching and wrinkling of the skin which remained problematic even under multispectral and infrared enhancement. Recognition of the tattoo markings also presented interpretive challenges in the possibility that it was not necessarily clear whether multiple figurative or textual elements arranged closely together might have been conceived as parts of a single motif. The assessment made by the first author was that 60 individual motifs could be discerned, although this figure should be understood only as a 'best judgement'. The majority of elements were pictorial representations (Table 1). There were also nine motifs comprising one or more elements of written text. Only two of these were legible under normal light, whilst the multispectral lights failed to improve upon this. However, the infrared imaging significantly clarified the remainder, offering some particularly specific insights.

\section{Pictorial images}

Many of the figurative tattooed elements included recurring types of motif that lent themselves to division into broad categories (Fig. 9). However, as is often the case with culturally generated signs, it was impossible to place every example in a single discrete category without some overlapping between groups, with competing possibilities apparent as to how such categories might be set. For example, a category of 'floral' motifs included some designs that simply consisted of flowers, but with others including a human hand holding a flower. A further example of two clasped hands (without flowers) illustrates the point that a further category of 'hands' could be generated, which would be 'correct' in and of itself, but which might achieve little in terms of aiding understanding of any possible meanings amongst the overall range of designs. The categories presented in Fig. 9 are therefore simply the least contentious set of groupings the first author was able to arrive at, but from which some clear, general observations can be made.

The most common image type comprised human figures either as full figures, the head and shoulders, or just faces. Of these, eleven were apparently of male gender, with eight female and seven indeterminate. Amongst the male gendered figures, there was an emphasis on variety, with a range of styles of facial hair and accessories, including a crown, a kepi and a clown's pointed hat and (presumably) red nose. The male figures also included an apparent sub-group wearing 'Arabic' style dress including turbans, a fez and a turbaned figure wearing voluminous trousers. These latter are of further interest in relation to a crescent and star tattoo motif, familiar today as a general symbol of Islam but which was specific to the Ottoman Empire in the nineteenth century (Glassé 2002). It may be of note in this regard that France annexed various former Ottoman territories in North Africa during the mid to late nineteenth century (Ágostan and Masters 2009). The female figures could be divided into homogeneous nudes and more varied figures with differing styles of hair and possible accessories such as hats, although the details of the latter were difficult to discern. One female individual (depicted from the shoulders up) stood out for having a distinctive hairstyle and

Fig. 9 Tattoo motifs by category 
more detailed dress that was plausibly interpreted as a portrait of a specific individual. Swords or daggers were a recurrent motif; in two cases, multiple 'daggers' were depicted piercing a heart, whilst other motifs defied categorisation such as the aforementioned image of the man chained to a column, or the image of a horizontal tricolour flag with stars in the upper bar. The floral motifs mentioned above may correspond with other nineteenth century flower tattoos noted by Caplan (2000b) to have symbolised hope. An image of an anchor was also a point of interest that is discussed below.

\section{Textual elements}

The tattooed elements with the greatest potential to provide insights regarding the identity and personality of this individual were the various pieces of text. Of course, these inked inscriptions also offer the greatest possibility for misinterpretation. In this regard, we have attempted to restrain speculation as much as possible and only present the most basic suggestions here. The most striking piece of text is arguably the word 'BONHEUR' tattooed in upper case above the individual's genitalia. Lombroso (1876) illustrated several individuals with tattooed penises comprising humorous images or text and it is tempting to speculate that the 'Bonheur' tattoo might have been one component of a motif that included other elements below, which are no longer present, as the individual's genitalia are not part of the preserved skin mounting. The name 'Flourine' appears in two places, one of which is below the female image noted above that appears to be a portrait. Both inscriptions indicate a relationship, which may place $\mathrm{M}$. Bonheur in an even more unique position. Whilst records exist of such romantic emblems involving tattooed depictions of named individuals (Caplan 2000b), we are unaware of any other example of preserved human remains from past populations which provide evidence for an individual's sense of humour or romantic relationships. The aforementioned anchor motif might most obviously be taken to denote a seafarer, although anchors have also been noted amongst nineteenth century tattoo motifs as general symbols of hope (MaxwellStewart and Duffield 2000). However, the words 'Vive La Flotte' (Fr: 'Long live the Fleet') revealed by the infrared analysis rather indicate the former, as both suggest naval service. As such a career necessarily entails foreign travel, it is plausible to suggest that some of the other tattoos, such as the 'Arabic' or perhaps North African motifs noted above, might then relate to places M. Bonheur had visited, rather than simply being evocative or exotic images chosen from a generic selection of motifs.

Three pieces of text were impossible to fully discern even with the benefit of infrared enhancement. The first of these reads 'Le Coeur' (Fr: the heart). It was unclear whether other text had originally been present. The second was the words 'Amis de' (Fr: 'friends of..') which presumably had further text that is now unrecognisable, whilst the third inscription (possibly) '18...RIP...' was part of a motif that may depict a skull next to a gravestone, although this interpretation remains uncertain. One surprise revealed on infrared in an otherwise darkened patch of skin was a motif comprising two crossed swords with the words 'Mort aux Commissaires' (Fr: 'Death to "Commissioners"'). This latter term is difficult to interpret in the absence of other information, but might refer to Commissaire de Police Judiciaire, a senior police rank. With regard to the suggestions elsewhere in the current article that M. Bonheur may have ended his life in prison, it is tempting to interpret this latter tattoo as a reference to his arrest or conviction. Arguably, the most enigmatic design was the aforementioned image of the uniformed man chained to a pillar, being brought his 'liberté' in a bird's beak. This design would certainly appear to suggest imprisonment and begs the question of the significance of the numbers ' 1883 ' at the base of the pillar and whether this referred to the date of his incarceration or the projected date of release.

\section{Discussion}

\section{A unique survival}

As far as the present authors are aware, the skin of M. Bonheur is unique in Europe. Whilst examples of incised tattooed skin exist in various nineteenth century medical collections, these are generally fairly small portions of skin (generally $<6$ inches diameter) mostly comprising only single tattoo motifs. For example, the Wellcome Collection, London, curates approximately 300 specimens of tattooed skin, collected in nineteenth century France from 'sailors, soldiers, murderers and criminals...' (Johnston-Saint cited in Angel 2017). A further collection at the Dept. of Forensic Medicine in the Jagiellonian University, Krakow, houses around 60 specimens, collected in the early twentieth century from inmates of the local Montelpich Street prison. The Museum National d'Histoire naturelle (Paris) holds 56 preserved skin specimens, whilst the Instituto Nacional de Medicina Legal e Ciências Forenses (Lisbon) curates 70 examples (Angel 2013). These small samples contrast markedly with examples of more complete flayed skins curated in Japan, mostly residing in the Pathology Department of the University of Tokyo. Whilst in the West, tattoos predating the late twentieth century were generally small, independent designs, in Japan, large 'bodysuits' developed involving one large, contiguous design covering either the full body, or the torso and upper limbs. Tattooing was outlawed in Japan in 1871 ostensibly on the basis of public health concerns, but prevailed as an art form amongst marginalised groups. Specifically, the acquisition of a full-body tattoo signified allegiance to the organised criminal fraternities known as the Yakuza, functioning to prove the 
ability to withstand pain and the risk of being poisoned by toxic pigments, whilst also demonstrating loyalty by its permanence, cost and illegality (Kaplan and Dubro 2003). Those financially unable to complete their tattoos often approached museums and private collectors, asking them to pay for their tattoos on promise of donating their skins to their collections at death (Van Dinter 2005). As the only European example of which the current authors are aware, comprising such a large portion of preserved tattooed skin from the nineteenth century, M. Bonheur would therefore appear to have no documented parallels outside Japan.

\section{Embodied symbolism: from the generic to the individual}

By the latter half of the nineteenth century, tattoos were no longer the novelty they had been during the early years following Cook's voyages to the Pacific, having instead become commonplace at least amongst certain sections of European society. By this time, tattoos had become a means of social signalling primarily (but by no means exclusively) amongst males, who identified themselves as being in some way distinct and separate from mainstream society either through service at sea or in the military, or through involvement in criminal activity (Bradley 2000). On this basis, the French anthropometrist Bertillon (1885) advocated the recording of tattoos as a potential means of identifying criminal recidivists. Prior to finger-printing, the possibility of identifying criminals in this way was one of the few such methods contemporary authorities could regard as 'reliable' (Maxwell-Stewart and Duffield 2000). However, other commentaries from this time went further in viewing tattoos as a means of recognising 'criminals' as an intrinsic class of individual, rather than just a means of identifying particular offenders. Such works were produced within a wider context of pseudoscientific endeavour purporting to identify and characterise particular personality types and their supposed physical expressions through practices such as physiognomy and phrenology, with particular attention paid to supposed abnormal features indicative of criminality or moral deficiency. Arguably the most widely cited author of such works is the Italian early criminologist Cesare Lombroso whose book Criminal Man appeared in five successive editions published between 1876 and 1897. This work was in turn produced against a wider background of early anthropological studies founded on the principal of establishing hierarchies of sex, race and class as biological facts, dating back to Samuel Morton half a century earlier.

Whilst Lombroso's claims carry no scientific weight today, an aspect of his work that remains useful is the attention he gave to documenting styles and meanings of tattoos during this period. With regard to the current study, Lombroso's illustrations, along with other examples presented by Caplan (2000b), are helpful in that they include various motifs that are similar both in style and in content to many of those on the skin of M. Bonheur, and so further bolster the interpretation of this individual having lived during the later nineteenth century. Examples such as an initially confusing motif that was clarified using multispectral light as being a sword or dagger piercing the skin, a flag, clasped hands, hearts, flowers, nudes and couples in sexual positions were shown to be part of a standard repertoire of designs that were popular at the time. Further, the presence of tattoos close to (and on) the genitals also has documented parallels rather than being unique to $\mathrm{M}$. Bonheur. However, Lombroso also illustrated a number of examples of tattoos comprising names, dates and pieces of text that can only be interpreted as having strong personal significance for the respective individuals. For example ' $L e$ passe me tourment, la present me l'avenir ni epouvant' roughly (Fr.) 'The past torments me, the present and future hold no terror'. Also the inclusion of dates, names and portraits of individuals, particularly romantic acquaintances, also seem to have been commonplace amongst tattooed individuals.

In studying the preserved samples of tattooed skin curated in the Wellcome Collection, London, Angel (2017) discusses the likelihood that many of these came from navy and army servicemen in French North Africa. Amongst these are various examples of 'souvenir' tattoos acquired by individuals as reminders of locations they had travelled to or served in. Several of these examples had tattoos referencing 'Zouave' regiments; these were light infantry regiments initially raised from the local population of Algeria, but later comprised of individuals from throughout France and its colonies. In particular, Angel (2017) illustrates one example comprising a crescent moon and star, which formed part of the insignia of various Zouave units, on which basis it can be speculated that the subject of the current study may again have served in the region in the context of the French armed forces. Other examples in the Wellcome collection were taken from individuals serving in French penal batallions composed of both military and civilian criminals, which is a further possibility that would appear plausible in respect to the character of several of $\mathrm{M}$. Bonheur's tattoos.

An important point to emerge from the current study is that the very personal nature of many of M. Bonheur's tattoos would appear to contradict the notion that the association of personal meanings to tattoos is a recent innovation restricted to the modern, western middle classes as claimed in some recent sociological studies (De Mello 2000; Madfis and Arford 2013). These latter works specifically contrast the 'personalised' and 'meaningful' status of modern tattoos with attitudes amongst the marginalised and socioeconomically disadvantaged groups that acquired tattoos in earlier times. The latter are claimed simply to have picked standard tattoo motifs from a limited range of generic designs that therefore lacked the deep personal symbolism which the modern, educated middle classes attach to their tattoos (De Mello 2000; 
Madfis and Arford 2013). Contrary to this notion, Bradley (2000) discusses nineteenth century tattoos as commonly holding very specific personal significance for their wearers. The clearly very personal nature of many of M. Bonheur's tattoos stands as examples of such, contradicting the assumption that tattooed people from earlier periods could be characterised as unthinking and uneducated social deviants simply following a fashion. By dismissing tattooed people from earlier periods as uncultured individuals, incapable of original ideas or a desire for personal expression, such thinking arguably continues to dehumanise these people in the same manner as Lombroso and his contemporaries.

Perhaps the most important effect of the biological determinist paradigm exemplified by Lombroso's work in relation to the current study is that such thinking may ultimately be the reason why M. Bonheur's skin has survived at all. It was standard nineteenth century practice for institutions such as prisons and asylums to release unclaimed bodies to medical practitioners for anatomical dissection; hence, many of the surviving nineteenth century tattoo specimens in museum collections were taken from deceased prisoners. It is plausible to suggest that the excision of this man's skin was carried out after his death in an institution, such as a military/naval context or a prison. Such a circumstance could explain the medical involvement with M. Bonheur's skin, which appears to have been excised following his autopsy. In bearing so many tattoos, this individual's body had become a kind of artefact whilst he was alive, as are all bodies in a way (Robb and Harris 2013). In this case, however, this man's skin then further became incorporated as an artificial preparation after death, first with the application of considerable medical skill and then through further modification in the mounting of his skin for display. If the date on the pillar to which the tattooed figure in the (convicts?) uniform was chained, '1883' did indeed refer to a date of release from prison or military servitude, then it would appear that for this individual that day never came. The portion of flayed skin then appears to have come into the possession of others who placed it on display. The practice of displaying tattoos would accord with an established nineteenth century tradition whereby heavily tattooed (living) individuals exhibited themselves for entertainment (Oettermann 2000). If this suggestion is true, it implies a European example of the 'sideshow mummy' phenomenon that was prevalent in the USA during the nineteenth and early twentieth century. Here unclaimed, embalmed bodies were exhibited for profit in circus sideshow and fairground attractions, commonly with a fictional or at least highly embellished story attached in order to increase their interest and profitability (Conlogue et al. 2008). In this respect, the story attached to M. Bonheur that was told to its current curator at the point the skin was purchased may in fact be of some antiquity and would also be consistent with this interpretation as 'marketing' for such an attraction.

\section{Conclusion}

Tattoos are often described as a phenomenon that sits at the interface between the cultural and the biological (Robb and Harris 2013). In this unusual example, the tattoo designs present offer unique insights into biographical details regarding the experiences, relationships and thoughts of an individual that would otherwise be completely inaccessible. Whilst a late nineteenth century date for this man is relatively secure, many aspects of his identity remain a mystery. However, the analyses presented and particularly the clarifications of the tattoo designs obtained via multispectral and infrared light have permitted us to obtain far more information than was first expected, and provided a more complete and personal narrative of this individual than is usually possible for anonymised human remains discovered through archaeological excavation. The reference to the fleet coupled with the anchor motif suggests a naval association. The story that the skin had originated in Marseilles would be consistent both with the principal Mediterranean base of the French Navy and with travel to North Africa or the Levant, as implied by other tattoos. The chained man being 'freed' may relate either to a completion of (naval/military?) service or the end of a prison sentencepresumably in 1883. Certainly, many preserved nineteenth century French tattoo specimens were taken from deceased prisoners by medical doctors. This would also explain the skilful removal of the skin and the incisions and stitching which are consistent with medical autopsy. The later crude repair, stuffing and fixture to a board plus the 'exciting story' that this man had been a convicted murderer suggests $M$. Bonheur was at some time displayed, presumably for profit as seen in various nineteenth-twentieth century 'sideshow mummies' known in the USA (Conlogue et al. 2008). Lastly, whilst M. Bonheur's real name remains unknown, perhaps the most personal aspect of this man's life to have been revealed is one of his relationships in the romantic mentions of a woman's name-'Flourine'.

Supplementary Information The online version contains supplementary material available at https://doi.org/10.1007/s12520-021-01290-8.

Acknowledgements We are highly indebted to Simon Costin for bringing M. Bonheur to our attention and for repeatedly granting access to him for study. We would like to thank Denise Richards and colleagues at the Radiography and Radiotherapy Dept. at Poole Hospital, Dorset, for use of their CT scanning facilities. We also thank Alex Otto for supplying equipment and instruction on the use of multispectral light and Paul Cheetham for advice on photogrammetric reconstruction. Many thanks to Basil Purdue (Home Office Pathologist) for sharing his opinion on the autopsy incisions and stitching. Fiona Petchey at the University of Waikato gave helpful advice on the viability of ${ }^{14} \mathrm{C}$ dating. We thank Peter Mattheus at the Museo d'Arte e Scienza, Milan, for undertaking the spectroscopic dating. The latter date was funded by Bournemouth University in support of an MSc dissertation project conducted by Richard Slater. The 3D Male figure used in Fig. 1 was generated using the facility provided by Clara.io 
Open Access This article is licensed under a Creative Commons Attribution 4.0 International License, which permits use, sharing, adaptation, distribution and reproduction in any medium or format, as long as you give appropriate credit to the original author(s) and the source, provide a link to the Creative Commons licence, and indicate if changes were made. The images or other third party material in this article are included in the article's Creative Commons licence, unless indicated otherwise in a credit line to the material. If material is not included in the article's Creative Commons licence and your intended use is not permitted by statutory regulation or exceeds the permitted use, you will need to obtain permission directly from the copyright holder. To view a copy of this licence, visit http://creativecommons.org/licenses/by/4.0/.

\section{References}

Agarwal SC (2016) Bone morphologies and histories: life course approaches in bioarchaeology. Yearb Phys Anthropol 159:S130-S149

Ágostan G, Masters B (2009) Encyclopaedia of the Ottoman Empire. Facts on File, New York

Alvrus A, Wright D, Merbs CF (2001) Examination of tattoos on mummified tissue using infra-red reflectography. J Archaeol Sci 28:395400

Anderson C (2000) Godna: inscribing Indian convicts in the nineteenth century. In: Caplan J (ed) Written on the Body: the Tattoo in European and American History. Reaktion, London, pp 102-117

Angel G (2013) In the skin: an ethnographic-historical approach to a museum collection of preserved tattoos. $\mathrm{PhD}$ Thesis, University College London.

Angel G (2015) Roses and daggers: expressions of emotional pain and devotion in nineteenth-century tattoos. In: Rosenthal C, Vanderbeke D (eds) Probing the Skin: Cultural Representations of Our Contact Zone. Cambridge Scholars Press, Cambridge, pp 211-238

Angel G (2016) Atavistic marks and risky practices: the tatoo in medicolegal debate 1850-1950. In: Reinarz J, Siena K (eds) A Medical History of Skin. Taylor and Francis, London, pp 165-180

Angel G (2017) Rediscovering the nineteenth century European tattoo: collections, contexts and techniques. In: Krutak L, Deter-Wolff A (eds) Ancient Ink: The Archaeology of Tattooing. University of Washington Press, Seattle, pp 107-129

Beattie (1930) A note on two skulls from Tenerife. Am J Phys Anthropol 14:447-449

Bertillon A (1885) Identification Anthropométrique: instructions Signalétiques. Nabu Press, Charleston (SC) [2010]

Blumenbach JF (1865) The anthropological treatises of Johann Friedrich Blumenbach. Anthropological Society, London [original thesis The Unity of Mankind pub.1775, 1781 and 1795]

Bradley J (2000) Body commodification? Class and tattoos in Victorian Britain. In: Caplan J (ed) Written on the Body: The Tattoo in European and American History. Reaktion, London, pp 136-155

Buikstra J, Beck L (eds) (2009) Bioarchaeology: the contextual analysis of human remains. Routledge, Oxford

Caplan J (ed) (2000a) Written on the body: the tattoo in European and American History. Reaktion, London

Caplan J (2000b) National tattooing: traditions of tattooing in nineteenthcentury Europe. In: Caplan J (ed) Written on the body: the tattoo in European and American History. Reaktion, London, pp 156-173

Conlogue J, Beckett R, Bailey Y, Posh J, Henderson D, Double G, King $\mathrm{T}$ (2008) Paleoimaging: the use of radiography, magnetic resonance, and endoscopy to examine mummified remains. J Radiol Nurs 27: $5-13$

Davis JB, Thurnam J (1865) Crania Britannica. privately printed, London.

De Mello M (2000) Bodies of inscription: a cultural history of the modern tattoo community. Duke University, Durham (NC)
Derry DE (1913) A case of hydrocephalus in an Egyptian of the Roman period. J Anat Physiol 48:436-458

Deter-Wolf A, Diaz-Granados C (2013) Drawing with great needles: ancient tattoo traditions of North America. University of Texas, Austin (TX)

Deter-Wolf A, Peres TM (2019) Tattoo bundles as archaeological correlates for ancient body ritual in eastern North America. In: Carmody S, Barrier CR (eds) Shaman, Priest, Practice, Belief: Materials of Ritual and Religion in Eastern North America. University of Alabama Press, pp 37-62

Deter-Wolf A, Robitaille B, Krutak L, Galliot S (2016) The world's oldest tattoos. J Archaeol Sci Rep 5:19-24

Ellison T (2018) The evolution of physical anthropology. Am J Phys Anthropol 165:615-625

Finkbeiner WE, Ursell PC, Davis RL (2009) Autopsy pathology: a manual and Atlas. Elsevier, Philadelphia, Atlas of Autopsy Pathology

Fleming J (2000) The Renaissance tattoo. In: Caplan J (ed) Written on the Body: The Tattoo in European and American History. Reaktion, London, pp 61-82

Friedman R, Antoine D, Talamo S, Reimer PJ, Taylor JH, Wills B, Mannino MA (2018) Natural mummies from Predynastic Egypt reveal the world's earliest figural tattoos. J Archaeol Sci 92:116-125

Germer R (1991) Mumien, Zeugen des Pharaonenreiches. Artemis Verlag, Zürich

Gillreath-Brown A, Deter-Wolf A, Adams KR, Lynch-Holm V, Fulgham S, Tushingham S, Lipe WD, Matson RG (2019) Redefining the age of tattooing in western North America: a 2000-year-old artifact from Utah. JArch Sci Rep 24:1064-1075

Glassé C (2002) The New Encyclopaedia of Islam. Alta Mira, New York

Gowland R (2015) Entangled lives: implications of the developmental origins of health and disease hypothesis for bioarchaeology and the life course. Am J Phys Anthropol 158:530-540

Gustafson M (2000) The tattoo in the later Roman Empire and beyond. In: Caplan J (ed) Written on the body: the tattoo in European and American History. Reaktion, London, pp 17-31

Hage P, Harary F, Milicic B (1996) Tattooing, gender and social stratification in Micro-Polynesia. J R Anthropol Inst 2:335-350

Isçan MY (1988) Rise of forensic anthropology. Yearb Phys Anthropol 31:203-230

IUPAC (International Union of Pure and Applied Chemistry) (2014) Compendium of Chemical Terminology Gold Book. Version 2.3.3.

Jones CP (1987) Tattooing and branding in Graeco-Roman antiquity. J Roman Stud 77:139-155

Jones CP (2000) Stigma and tattoo. In: Caplan J (ed) Written on the body: the tattoo in European and American History. Reaktion, London, pp $1-16$

Kaplan DE, Dubro A (2003) Yakuza: Japan's Criminal Underworld. University of California, Berkeley (CA)

Keith A (1911) An inquiry into the nature of skeletal changes in acromegaly. Lancet 1:993-1002

Knüsel CJ, Batt CM, Cook G, Montgomery J, Müldner G, Ogden AR, Palmer C, Stern B, Todd J, Wilson AS (2010) The identity of the St Bees Lady, Cumbria: an osteobiographical approach. Mediev Archaeol 54:271-311

Lacassagne A (1881) Tatouages, Étude Anthropologique et MédicoLégale. Nabu Press, Charlston (SC) [2014]

Lee W, Khoo B (2010) Forensic light sources for detection of biological evidences in crime scene investigation: a review. Malaysian J Foren Sci 1:17-27

Lessa A, Guidon L (2002) Osteobiographic analysis of Skeleton I, S1'tio Toca dos Coqueiros, Serra da Capivara National Park, Brazil, 11, 060 BP: first results. Am J Phys Anthropol 118:99-110

Little, M A, Sussman R W (2010) History of biological anthropology. In Larsen C S (ed.) A Companion to Biological Anthropology. Blackwell, Oxford, pp13-38. 
Lombroso C (1876-1896) Criminal man. five editions (transl. Gibson M, Rafter N) Duke University, London.

Madfis E, Arford T (2013) The dilemmas of embodied symbolic representation: regret in contemporary American tattoo narratives. Soc Sci J 50:547-556

Matthaes G (2002) Spectroscopic dating and classification of wood. Postprints of annual meetings of the Wooden Artefacts Group of the American Institute for Conservation. (available from: www. wag-aic.org).

Maxwell-Stewart H, Duffield I (2000) Skin deep devotions: religious tattoos and convict transportation to Australia. In: Caplan J (ed) Written on the Body: The Tattoo in European and American History. Reaktion, London, pp 118-135

Melton N, Montgomery J, Knüsel CJ (eds) (2013) Gristhorpe man: a life and death in the Bronze Age. Oxbow, Oxford

Morton SG (1839) Crania Americana. Dobson, Philadelphia

Oettermann S (2000) On display: tattooed entertainers in America and Germany. In: Caplan J (ed) Written on the Body: The Tattoo in European and American History. Reaktion, London, pp 193-211

Ortner D (2003) Identification of pathological conditions in human skeletal remains. Elsevier, London

Pabst M, Letofsky-Papst I, Bock E, Moser M, Dorfer L, Egarter-Vigl E, Hofer F (2009) The tattoos of the Tyrolean Iceman: a light microscopical, ultrastructural and element analytical study. J Archaeol Sci 36:2335-2341

Pabst M, Letofsky-Papst I, Moser M, Spindler K, Bock E, Wilhelm P, Dorfer L, Geigl J, Auer M, Speicher M, Hofer F (2010) Different staining substances were used in decorative and therapeutic tattoos in a 1000-year-old Peruvian mummy. J Archaeol Sci 37:3256-3262

Robb J, Harris OT (2013) The body in history: Europe from the Palaeolithic to the future. Cambridge University, Cambridge

Robb J, Inskip SA, Cessford C, Dittmar J, Kivisild T, Mitchell PD, Mulder B, O'Connell TC, Price ME, Rose A, Scheib C (2019) Osteobiography: the history of the body as real bottom- line history. Bioarch Int 3:16-31

Roberts CA, Cox M (2003) Health and disease in Britain: from prehistory to the present day. Sutton Publishing, Gloucester
Allen-Rosecrans J (2000) Wearing the universe: symbolic markings in Eraly Modern England. In: Caplan J (ed) Written on the body: the tattoo in European and American History. Reaktion, London, pp 46-60

Samadelli M, Melisc M, Miccolic M, Vigld EE, Zink AR (2015) Complete mapping of the tattoos of the 5300-year-old Tyrolean Iceman. J Cult Herit 16:753-758

Slater, R. (2011) Hung out to dry: a multidisciplinary analysis and recording of a preserved 19th century tattooed human skin. MSc Dissertation submitted to Bournemouth University, UK.

Sperry K (1992) Tattoos and tattooing, Part II: gross pathology, histopathology, medical complications and applications. Am J Foren Med Path 13:7-17

Starkie A, Birch W, Ferllini R, Thompson TJU (2011) Investigation into the merits of infrared imaging in the investigation of tattoos postmortem. J Foren Sci 56:1569-1573

Stodder A, Palkovich A (eds) (2012) The bioarcheology of individuals. University Press Florida, Gainseville (FL)

Thomas N, Cole A, Douglas B (eds) (2005) Tattoo: bodies, art and exchange in the Pacific and the West. Duke University, Durham (NC)

Tilley L, Oxenham M (2011) Survival against the odds: modeling the social implications of care provision to seriously disabled individuals. Int J Paleopathol 1:35-42

Tilley L, Schrenk A (eds) (2016) New developments in the bioarchaeology of Care. Springer, New York

Van Dinter MH (2005) The world of tattoo: an illustrated history. KIT Publishing, Amsterdam

Walker PL (2000) A view on the science: physical anthropology at the millennium. Am J Phys Anthropol 112:145-148

Walker PL (2008) Sexing skulls using discriminant function analysis of visually assessed traits. Am J Phys Anthropol 136:39-50

Publisher's note Springer Nature remains neutral with regard to jurisdictional claims in published maps and institutional affiliations. 